\title{
Motor neuron vulnerability and resistance in amyotrophic lateral sclerosis
}

\author{
Jik Nijssen $^{1} \cdot$ Laura H. Comley $^{1}$ - Eva Hedlund ${ }^{1} \mathbb{C}$
}

Received: 31 January 2017 / Revised: 29 March 2017 / Accepted: 1 April 2017 / Published online: 13 April 2017

(c) The Author(s) 2017. This article is an open access publication

\begin{abstract}
In the fatal disease-amyotrophic lateral sclerosis (ALS)-upper (corticospinal) motor neurons (MNs) and lower somatic MNs, which innervate voluntary muscles, degenerate. Importantly, certain lower MN subgroups are relatively resistant to degeneration, even though pathogenic proteins are typically ubiquitously expressed. Ocular MNs (OMNs), including the oculomotor, trochlear and abducens nuclei (CNIII, IV and VI), which regulate eye movement, persist throughout the disease. Consequently, eye-tracking devices are used to enable paralysed ALS patients (who can no longer speak) to communicate. Additionally, there is a gradient of vulnerability among spinal MNs. Those innervating fast-twitch muscle are most severely affected and degenerate first. MNs innervating slow-twitch muscle can compensate temporarily for the loss of their neighbours by re-innervating denervated muscle until later in disease these too degenerate. The resistant OMNs and the associated extraocular muscles (EOMs) are anatomically and functionally very different from other motor units. The EOMs have a unique set of myosin heavy chains, placing them outside the classical characterization spectrum of all skeletal muscle. Moreover, EOMs have multiple neuromuscular innervation sites per single myofibre. Spinal fast and slow motor units show differences in their dendritic arborisations and the number of myofibres they innervate. These motor units also differ in their functionality and excitability. Identifying the molecular basis of cell-intrinsic
\end{abstract}

Jik Nijssen

jik.nijssen@ki.se

$\triangle$ Eva Hedlund

eva.hedlund@ki.se

1 Department of Neuroscience, Karolinska Institutet, Retzius v. 8, 17177 Stockholm, Sweden pathways that are differentially activated between resistant and vulnerable MNs could reveal mechanisms of selective neuronal resistance, degeneration and regeneration and lead to therapies preventing progressive MN loss in ALS. Illustrating this, overexpression of OMN-enriched genes in spinal MNs, as well as suppression of fast spinal MN-enriched genes can increase the lifespan of ALS mice. Here, we discuss the pattern of lower MN degeneration in ALS and review the current literature on OMN resistance in ALS and differential spinal $\mathrm{MN}$ vulnerability. We also reflect upon the non-cell autonomous components that are involved in lower MN degeneration in ALS.

Keywords Oculomotor neuron $\cdot$ Fast and slow motor units - Selective vulnerability $\cdot$ Neurodegeneration - ALS · Neuromuscular junction

\section{Introduction}

Initially described by Jean-Martin Charcot in 1869, amyotrophic lateral sclerosis (ALS) is a neurodegenerative disease targeting the motor neuron (MN) system required for voluntary movement. MNs of the autonomic system are less affected [141]. Progressive degeneration of a large proportion of upper (corticospinal) and lower somatic MNs leads to spasticity, muscle atrophy and resulting weakness of skeletal muscles. The first symptoms typically arise in one or more limbs (spinal onset). About $20 \%$ of cases present with a bulbar onset, where speech and swallowing problems are noticed first. Whereas spinal onset ALS is fatal at 3-5 years postdiagnosis, bulbar onset ALS patients face a worse prognosis with an average survival of only 2 years. Paralysis of respiratory muscles and subsequent respiratory 
dysfunction is the cause of death. In a small minority of patients $(3-5 \%)$ onset of disease occurs in respiratory muscles. This respiratory onset form of ALS has an even shorter prognosis with an average life expectancy of only 1.4 years [171].

The incidence of ALS in Europe is 1-2.5 cases per 100,000 person years, being more common in men than in women at a ratio of 1.3 . The point prevalence is approximately 4-6 cases per 100,000 people [1]. The majority of cases occurs without a clearly identifiable hereditary or environmental cause and is identified as sporadic ALS (sALS). Approximately $10 \%$ of cases demonstrate direct inheritance (familial ALS; fALS). The first gene discovered to harbour mutations causing fALS was the $\mathrm{Cu} / \mathrm{Zn}$ superoxide dismutase 1 (SODl) gene [153]. It is estimated that mutations in this gene are responsible for between 10 and $25 \%$ of fALS cases and $1-2.5 \%$ of all ALS cases. These mutations are thought to induce a toxic gain-of-function of the protein, which becomes prone to misfolding and subsequent aggregation. Subsequently, mutations in several genes have been discovered to underlie ALS, with the most common being TAR DNA binding protein (TARDBP), Fused in Sarcoma (FUS) and Chromosome 9 open reading frame 72 (C9ORF72) [38, 101, 136, 148, 183]. TDP-43, the protein product of TARDBP, and FUS are known RNA-binding proteins with several functions in processing and maturation of RNAs [102]. For TDP-43, a loss of nuclear function due to mislocalisation to the cytosol is thought to trigger ALS [187]. For FUS, mislocalisation also occurs, but here a toxic gain-of-function in either cytoplasm or nucleus appears more likely as pathology still occurs regardless of the presence of normal FUS in the nucleus [128, 164, 170].

The function of the C9ORF72 protein has not yet been elucidated. A massive hexanucleotide repeat expansion in this gene was found to underlie both fALS and sALS cases $[38,148]$. It is currently the most common mutation identified in sALS patients. A loss-of-function pathology was initially proposed as the massive expansion was thought to disrupt the normal function of the protein. However, mice lacking the C9ORF72 homologue do not develop a motorrelated phenotype [7, 169]. A gain-of-function is, therefore, more likely. It is debated if pathology arises from a gain-offunction at the RNA or protein level or both. RNA-protein aggregates called RNA foci were detected, as well as protein products arising through repeat-associated non-ATG dependent translation (reviewed in [15, 60, 190]).

Genes found to be mutated in ALS are ubiquitously expressed throughout the nervous system as well as in various other tissues, but selectively cause degeneration of somatic MNs. It is currently unclear why these MNs are so vulnerable to mutations in SOD1, FUS, TDP-43 and C9ORF72.

Furthermore, while upper and lower somatic MNs are selectively targeted in ALS, some lower MN subgroups are relatively resistant to degeneration [34, 73]. Selective vulnerability occurs at different levels in the motor system (Fig. 1). Neurons of the oculomotor (CNIII), trochlear (CNIV) and abducens (CNVI) nuclei, which are located in the midbrain and control eye movement, show marked resistance to degeneration in ALS. This allows patients even in late stages of disease to communicate using eye movements, often computer-aided [28, 98]. Additionally, MNs innervating pelvic floor muscles remain relatively unaffected, generally preventing incontinence in ALS patients [30]. Furthermore, there is a gradient of vulnerability among spinal MNs where faster motor units become affected before slower types [147]. Consequently, 'fast' muscles relying mainly on glycolysis become paralysed before slow types with a more oxidative metabolism [74].

The reasons for the differential vulnerability among MNs remain largely unknown. Experiments conducted on fALS animal models where mutant SOD1 or TDP-43 have been selectively removed from specific cell types indicate that factors intrinsic to MNs are crucial for initiation of degeneration and early disease $[16,82,84,90]$. In mutant SOD1 models oligodendrocytes also appear important for initiation of disease [89], while inflammatory events elicited by astrocytes and microglia appear to drive disease progression [16, 54, 194]. Based on the importance of factors intrinsic to MNs for disease initiation, we believe that an analysis of the intrinsic properties of MNs displaying differential susceptibility to disease could reveal mechanisms of neuronal resistance and vulnerability. This in turn could lead to future therapies to prevent the progressive MN loss in ALS.

Here, we aim to review the literature regarding motor neuron degeneration in ALS. We will discuss the selective vulnerability between lower MN subgroups, focussing on the oculomotor system and the gradient of degeneration in the spinal cord. We also reflect upon the involvement of non-cell autonomous events in MN degeneration in ALS.

\section{Motor neuron degeneration in ALS}

Of clear interest to the field of ALS therapeutics is the identification of the primary site of visible pathology within vulnerable MNs, which consist of three clearly defined subcompartments-soma, axon and synapse. A therapy targeting a secondary site of pathogenesis may be too late to have any positive effect on disease outcome.

Careful studies using the $\mathrm{SOD} 1^{\mathrm{G} 93 \mathrm{~A}}$ mouse model have investigated the time course of distal and proximal events within MNs [52, 111, 185]. Different genetic backgrounds are known to change the timeline of pathology in SOD $1^{\mathrm{G} 93 \mathrm{~A}}$ mice, but the pattern of dying-back pathology holds true. One study (where background was not 


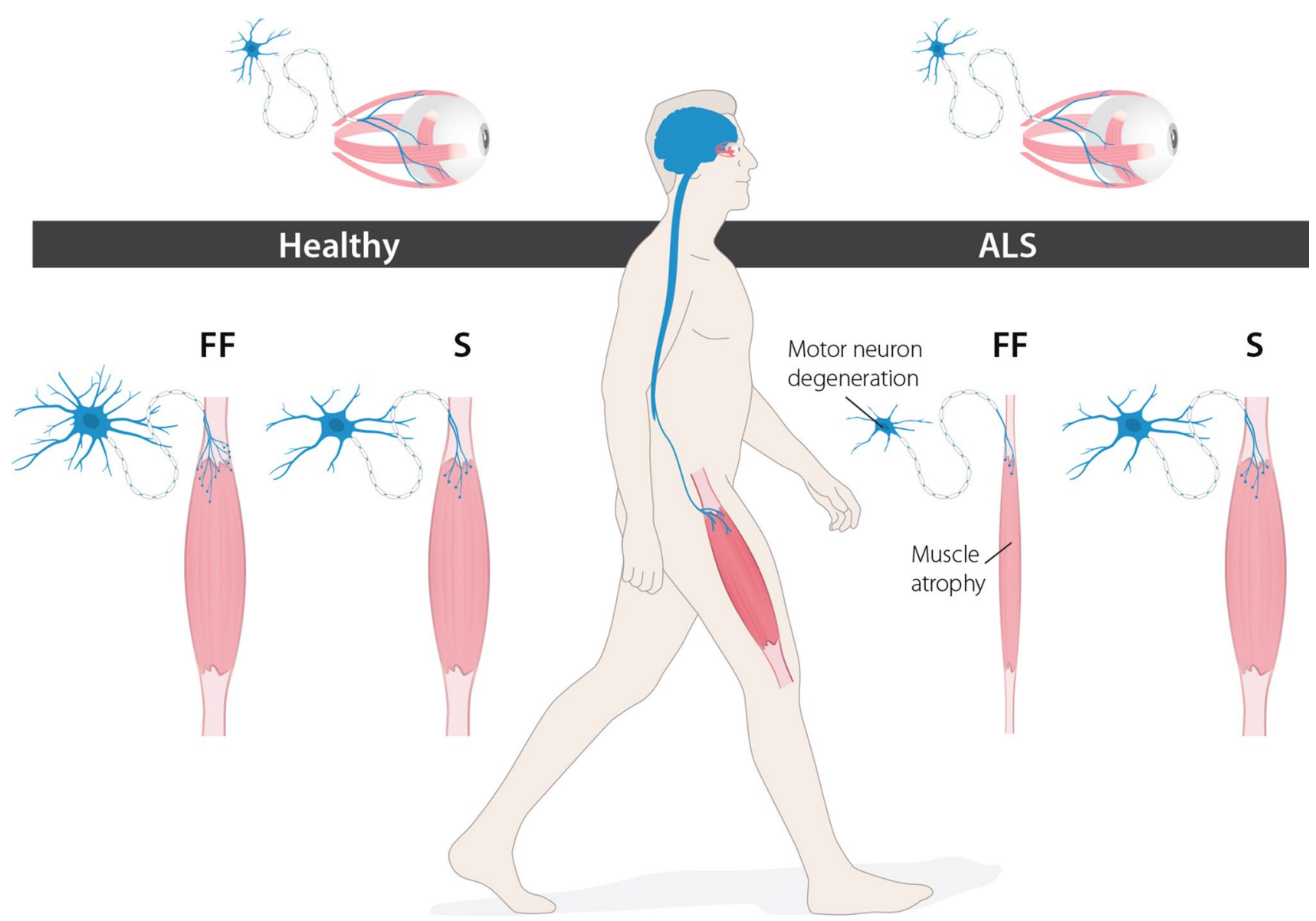

Fig. 1 Levels of selective vulnerability in ALS. ALS selectively affects the somatic motor neuron system. Specific motor neuron pools are more resistant, such as the oculomotor neurons, which persist until end-stage of disease. Additionally, subtypes of affected spinal

specified) found denervation of NMJs in hind limb muscle at postnatal day (P)47, well before the loss of $\mathrm{MN}$ somas at $\mathrm{P} 100$ and a decrease in rotarod performance from P78 [52]. A similar pattern was also reported by others (in SOD1 $1^{\mathrm{G} 93 \mathrm{~A}}$ mice on a mixed B6SJL and C57B1/6 background) with a decrease in rotarod performance at $\mathrm{P} 60$ preceding the loss of MN somas that occurred after P90 [111]. Also in B6SJL (high expressor) mice denervation at $\mathrm{P} 30$ preceded MN loss at P60 [185]. A similar dying-back pattern beginning at neuromuscular synapses was reported also in motoneuron degeneration (Mnd) and progressive motoneuronopathy (pmn) mice, indicating that the NMJ is vulnerable early across diseases with distinct underlying pathological processes [55].

Dying-back pathology is also seen in ALS patients, as initially reported by histological analysis of a patient who died unexpectedly prior to end-stage. Muscle atrophy and denervation were evident in skeletal muscles of the legs and thorax, but no axonal degeneration was observed motor neurons also display a gradient of vulnerability. Fast-twitch fast-fatigable (FF) motor neurons degenerate before slow (S) motor neurons

within the ventral roots and normal numbers of MNs were present within the spinal cord [52]. In ALS patients, electrophysiology has been used to demonstrate early transmission changes in several different muscles. It has been reported that patients have decreased amplitudes of miniature endplate potentials (small depolarisations of the postsynaptic terminal caused by the spontaneous release of a single vesicle of acetylcholine) [119] and a decrease in twitch force of muscle units [41]. Recently, morphological analysis of NMJs was correlated with clinical and electrophysiological data from nine ALS patients, of whom five were early-stage patients and four were longterm survivors of the disease. Morphological abnormalities were found in the incoming nerve, the muscle and the terminal Schwann cells in both early-stage patients and long-term survivors, suggesting again that alterations at the NMJ are present early on in the disease [20].

In line with these results it has been shown that preserving MN somas alone is not enough to rescue mutant SOD1 
mice because the axons cannot reconnect at the NMJ once they have retracted enough $[42,62,155]$. This supports the notion that therapy should be aimed at both the soma and the NMJ to optimise the beneficial effect.

Furthermore, in the SOD $1^{\mathrm{G} 93 \mathrm{~A}}$ mouse upper MNs also appear vulnerable in a dying-back fashion [138]. However, an alternate degeneration pattern can be triggered in these neurons. For example, the loss of ubiquitin C-terminal hydrolase-L1 (UCHL1) caused progressive dying-forward of corticospinal MNs, affecting the cell body first and progressing towards the spinal cord. Meanwhile, interestingly, spinal MNs displayed strong dying-back pathology, with pronounced NMJ denervation but leaving spinal MN numbers unaffected [58]. This indicates that the mechanisms responsible for degeneration and coping mechanisms of upper and lower MNs cope appear distinct.

\section{The oculomotor system}

In mammals, there are six extraocular muscles (EOMs) controlling eye movement. Of these, four are innervated by MNs in the oculomotor nucleus (superior rectus, medial rectus, inferior rectus and inferior oblique). Of the remaining two, the superior oblique is innervated by neurons from the trochlear nucleus, while the lateral rectus is innervated by the abducens nerve.

The EOMs are unique in a number of respects, confounding the task of identifying the key differences responsible for their protection from degeneration in $\mathrm{MN}$ diseases (see Box 1).

\section{Anatomy and innervation pattern of the oculomotor system}

First, EOMs have a different pattern of innervation compared to almost all skeletal muscles. The majority of skeletal muscles have a single point of contact between each muscle fibre and an incoming axon at the NMJ. These NMJs are usually located towards the centre of the fibre, giving rise to the so-called en plaque endplates. While $80 \%$ of EOM fibres conform to this pattern of singly innervated fibres (SIFs) the remainder consists of multiply-innervated fibres (MIFs). Multiple innervation is achieved with smaller endplates compared to the en plaque type, which are organised in grape-like structures, leading to the name en grappe endplates. These endplates are located in distinct, more distal bands of the muscle, spatially separated from the regular en plaque
SIF endplates on the muscle belly region (Fig. 2). In addition to an en plaque endplate, multiple en grappe endings can be present on the same myofibre, interconnected by the same axon [199]. The MIFs do not respond with the typical 'all-or-nothing' rapid twitch response but instead allow for small graded contractions [142, 167]. These contractions remain local and are not propagated along the muscle fibre. It was suggested that these localized, slow contractions finely modulate eye movement or dampen the strong twitch contractions for more stable vision [85]. They also incorporate sensory functions, allowing for reflexive eye movements such as gaze fixation [26, 199]. The somas of both SIF- and MIF-innervating neurons are located in the oculomotor nucleus in the midbrain. MIF-innervating neurons are present in the periphery of this nucleus, while SIF-innervating neurons constitute the centre [27]. Moreover, these neurons receive different projections, likely related to the differential function of SIF and MIF fibres in ocular movement and reflexes [189].

Secondly, EOMs have a distinct composition of ten myosin heavy chain fibre types and uniquely express multiple types within a single myofibre [198]. This contrasts with skeletal muscle, which generally expresses a single isoform of myosin per fibre that is suited to the demands of that muscle. The range of myosin isoforms present in EOMs also includes embryonic and neonatal forms, which are only partly downregulated in adulthood [19], and $\alpha$-cardiac myosin, more typically found in smooth muscle of the heart [157] (see Box 1). As these isoforms contract relatively slowly compared to the other isoforms, they dampen MIF contraction [85].

EOMs also have a different immunological status, as they contain more negative regulators of the complement pathway. This is likely what renders the EOMs more vulnerable than skeletal muscles in the autoimmune neuromuscular disease myasthenia gravis [143].

Motor unit size is small in EOMs compared to other muscles (Fig. 3). Regular fast-twitch skeletal muscles have innervation ratios that often exceed 1:300; each single MN innervates at least 300 muscle fibres. This number can rise to 2,000 in large muscles such as the medial gastrocnemius [23, 25]. In EOMs, the innervation ratio is substantially lower, with ratios as low as 1:5 having been reported $[48,66]$ (see Box 2). The small motor unit size combined with the presence of multiple innervations likely allows for highly precise regulation of EOM tension and contraction. 


\section{Box 1: Oculomotor units}

Ocular motor units differ in several aspects from general motor units. Their muscle fibres cannot be classified using the regular slow-to-fast spectrum. In contrast to normal skeletal muscle, extra-ocular muscle fibres express multiple myosin heavy chain (MHC) isoforms, including embryonic and neonatal isoforms [19, 191]. Studies in mice have shown that these are spread in different patterns in the global (inner) and orbital (outer) muscle layers of the six extra-ocular muscles [154, 197]:

\section{Classical myosin heavy chains: \\ - Myhl (Type 2X - fast) \\ - $\quad$ Myh2 (Type 2A - fast) \\ distal ends of global layer \\ - $\quad$ Myh4 (Type 2B - fast) \\ distal ends of orbital layer \\ - $\quad$ Myh7 (Type 1 - slow) \\ distal ends of global layer \\ scattered throughout both layers}

Non-classical myosin heavy chains:

- Myh3 (embryonic)

- Myh6 ( $\alpha$-cardiac)

distal ends of orbital layer

- $\quad M y h 8$ (neonatal)

not well described

- Myh14 (slow-tonic)

distal ends of orbital layer

- Myh13 (extra-ocular)

- Myh15 (extra-ocular)

in a minor population of slow fibres only

muscle belly/innervation region of both layers

mainly in orbital layer

The embryonic and neonatal MHC isoforms make up almost $97 \%$ of all myosin present at P0 in mice. By 3 weeks of age, this is downregulated to approximately $8 \%$, which remains stable even until 3 months of age. In humans, a similar pattern was observed [189]. Myh15 was described to be absent during fetal stages, with expression starting after birth in mice [154]. The $\alpha$-cardiac MHC isoform has been described in both mice and rabbits, but not humans [157, 197].

The innervation ratio of ocular motor units is strikingly low, with one OMN innervating less than 20 myofibres [48, 66]. Morphologically, OMNs share similar features to fast spinal alpha MNs in that they have an average of 10 first-order dendrites that bifurcate approximately 5 times each $[63,177]$. However, dendritic and somatic volume is smaller in OMNs. Their dendritic span ranges from 1-2mm, compared to 2-3mm for spinal MNs [63, 79, 177].

However, OMNs differ strongly from spinal MNs in their higher excitability. They have a higher resting membrane potential of around $-61 \mathrm{mV}$ compared to $-70 \mathrm{mV}$ for spinal motor neurons $[175,176]$ and discharge at increased frequencies: around $100 \mathrm{~Hz}$ during steady gaze but rising to $600 \mathrm{~Hz}$ during saccadic eye movements [152]. For comparison, alpha MNs typically fire at frequencies below $100 \mathrm{~Hz}$. Moreover, OMNs are almost continually active at high frequencies, as they fire tonic discharges related to eye position even during steady gaze [37, 56]. It appears that increased activity correlates with resistance to neurodegeneration, since also the more resistant S MNs in the spinal cord have the highest activity time compared to their FF MN counterparts [77].

\section{Embryonic development of oculomotor neurons}

OMNs are generated in the ventral midbrain along with dopamine neurons, red nucleus neurons and GABAergic interneurons. These neuron types are specified by the signalling molecules Shh (sonic hedgehog), that is secreted from the floor plate and the notochord, Wnts (wingless-related MMTV integration site) and Fgf8 (fibroblast growth factor 8 ) that are secreted by and around the isthmic organiser [86, 121, 140, 144, 195]. These morphogens in turn regulate transcription factors that influence differentiation of ventral midbrain neurons [6, 40, 50, 71, 139, 146]. Specifically, OMNs are specified by the transcription factors Phox $2 a$, Phox $2 b$ and Lmx $1 b$. Phox $2 a$ is expressed already at embryonic day (E) 9 in the forming oculomotor and trochlear nuclei and present in both neuroepithelial precursors and differentiated neurons. Phox $2 b$ is expressed around E10.5 and then only in differentiating 

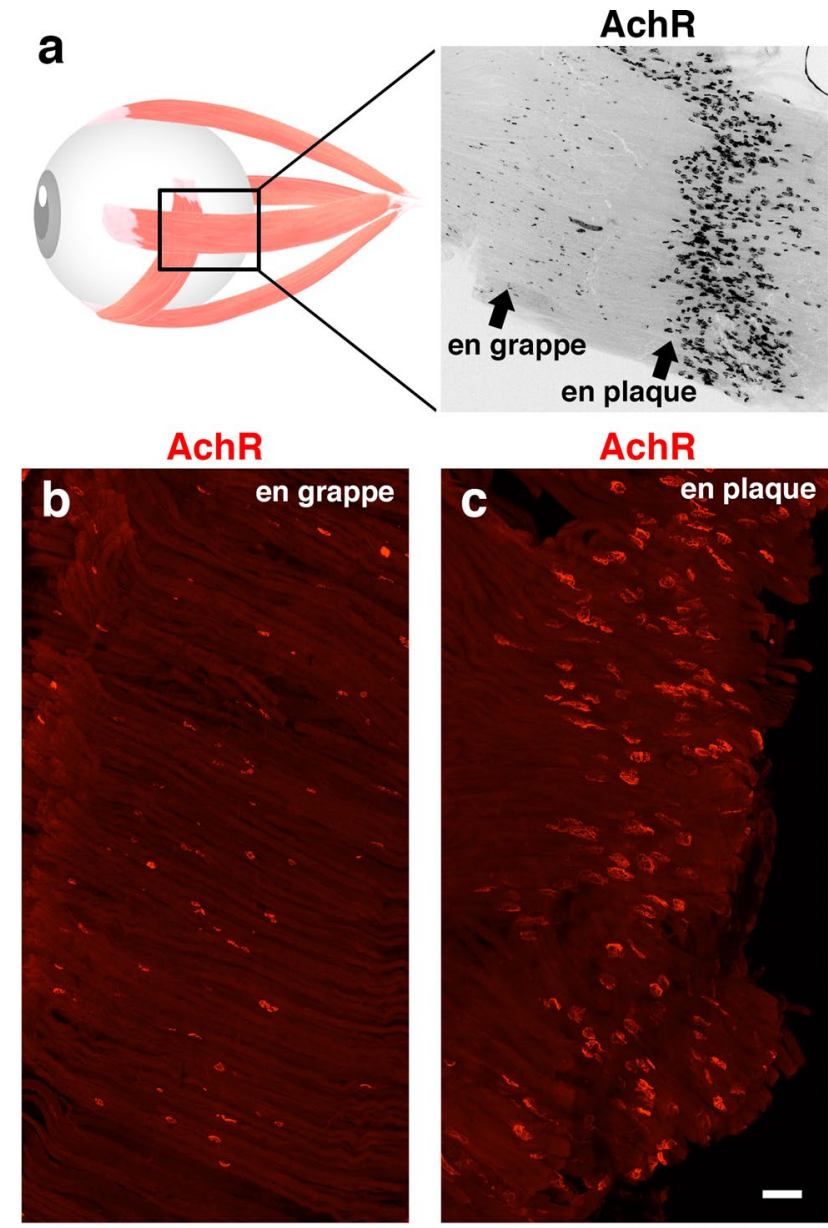

AchR SV2/NF

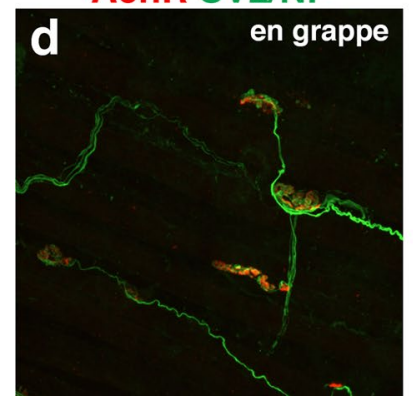

AchR SV2/NF

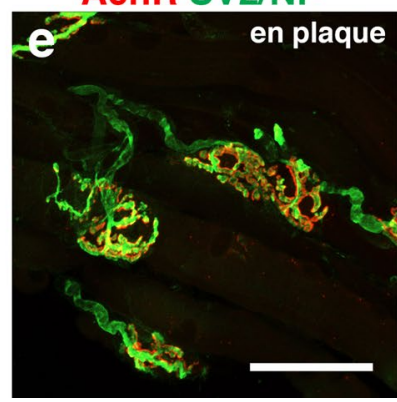

Fig. 2 Neuromuscular endplates in extraocular muscle. All six extraocular muscles in mammals have a unique arrangement of neuromuscular endplates. Two distinct bands (rather than one) can be observed (a). Extraocular muscles contain a unique band of small en grappe endplates $(\mathbf{b}, \mathbf{d})$, besides the regular band of normal-sized en plaque endplates (c, e). Multiple innervation occurs between bands, such that one muscle fibre can have multiple NMJs, one within each endplate band. Scale bars $50 \mu \mathrm{m}$, bars in $\mathbf{c}$ and $\mathbf{e}$ also apply also to b and d, respectively. AchR acetylcholine-receptor, SV2/NF synaptic vesicle protein 2 and neurofilament $165 \mathrm{kDa}$ neurons [139]. Lmx1b is required for the expression of Phox $2 \mathrm{a}$ [40]. Phox $2 \mathrm{a}$ in turn is required to drive OMN fate as demonstrated by the lack of both oculomotor and trochlear nuclei in Phox2a knockout mice [139]. Overexpression studies in the chick have demonstrated that Phox $2 \mathrm{a}$ is also sufficient to generate a complete oculomotor complex consisting of somatic OMNs and visceral Edinger-Westphal neurons [71, 139]. Phox2b on the other hand is sufficient to induce ectopic generation of OMNs in the spinal cord [47, 139], but it is not required for induction of OMN fate in the midbrain [47, 139]. In vitro studies have confirmed that overexpression of either Phox $2 a$ or Phox $2 b$ in neural progenitors exposed to Shh and Fgf8 can promote a midbrain/hindbrain MN fate [131]. Proper migration and axonal outgrowth of newly born OMNs appears regulated by the Shh-inducible transcription factor Nkx6.1 through the modulation of a number of migration/guidance cues including Unc5c, Robo1 and Slit2 [145]. OMNs express the LIM homeodomain transcription factors Islet-1 and 2 (Is11/2), but lack expression of the transcription factor $\mathrm{Hb} 9$, which defines other somatic MNs. The transcriptome and proteome of OMNs is consequently distinct from other somatic MNs [4, 18, 33, 73].

\section{Selective resistance of the oculomotor system in ALS}

Given the plethora of unique characteristics of the ocular motor system (Fig. 3) it is perhaps unsurprising that it responds differently in ALS compared to other motor units - remaining resistant to degeneration even at later stages of the disease. A study of 34 motor neuron disease (MND) patients reported normal ocular motor function compared to control subjects in all patients, except in the presence of Parkinsonism [61]. Clinically, this allows patients in later stages of different MNDs to use eye movement as a communication tool [28, 98]. A postmortem histological study revealed that the oculomotor nucleus was 'altered' in only 4 out of 50 patients studied [105]. No correlation between genetic background and the resistance of oculomotor neurons has been described, so it appears to be a consistent feature of ALS. Additionally, oculomotor resistance occurs across motor neuron diseases. In spinal muscular atrophy (SMA) patients ocular tracking devices are used in later stages of the disease to enable communication [98], indicating the resistance of OMNs. Furthermore, in a mouse model of SMA no denervation was observed in EOMs [34]. 


\section{Spinal motor neuron}

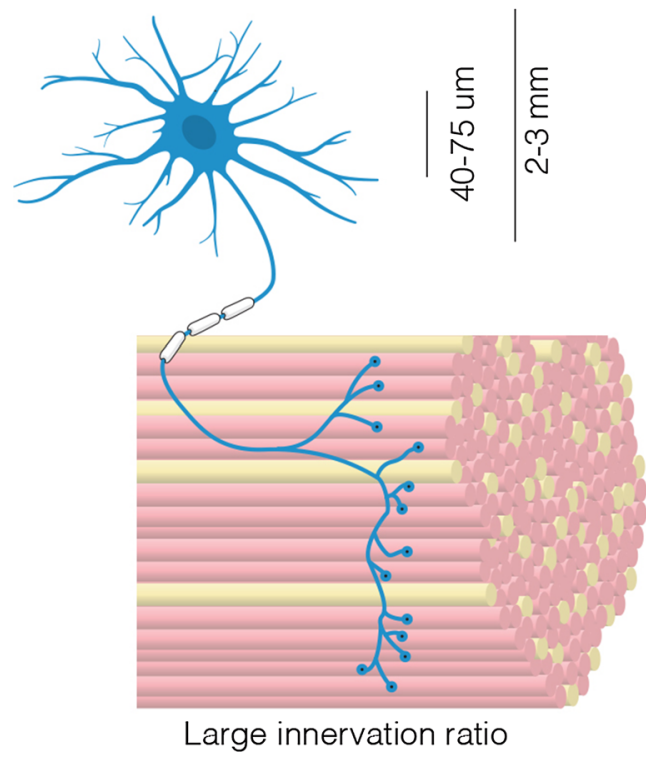

\section{Oculomotor neuron}

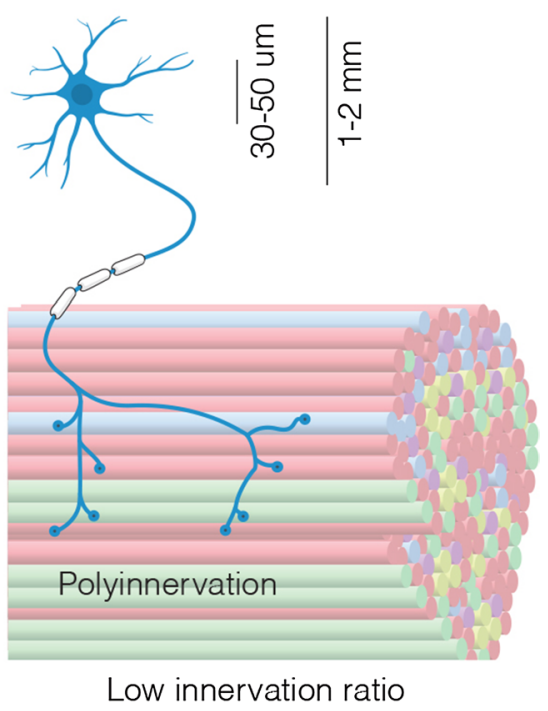

of muscle fibre. Extraocular muscle itself is more complex, containing many different fibre types, not only those containing the classical skeletal myosins. Oculomotor neurons innervate very few endplates compared to spinal motor neurons, but poly-innervation occurs on a large scale

levels of gliosis at this point, it is evident that a time course for glial activation in the brain stem is needed to conclude when and where activation occurs and if this is important for the differential MN vulnerability seen in the brain stem.

\section{Cell-intrinsic determinants of oculomotor neuron resistance}

The selective resistance of OMNs could offer potential clues to mechanisms underlying degeneration in ALS and define the molecular signature that renders a specific subset of neurons more resistant while others degenerate in the face of the same insult. To pinpoint these differences, we previously compared the global transcriptional profiles of OMNs, hypoglossal MNs and spinal MNs isolated by laser capture microdissection from 8-week-old normal Sprague-Dawley rats. This comparison of vulnerable and resistant MNs revealed enriched transcripts for each population [73]. At the protein level, we subsequently showed that OMNs, hypoglossal MNs and spinal MNs have distinct expression signatures [33]. $\mathrm{GABA}_{\mathrm{A}}$ receptor $\alpha 1$ (Gabra1), parvalbumin, guanylate cyclase soluble subunit alpha-3 (Gucy1a3) and insulin-like growth factor 2 (IGF-2) were persistently expressed in OMNs in mouse and man as confirmed also by immunohistochemistry and the resistant red nucleus showed several fold higher 
Table 1 Key molecules identified as enriched in resistant or vulnerable motor populations and their functional effect upon overexpression or suppression

\begin{tabular}{llll}
\hline Oculomotor enriched & Outcome & References \\
\hline IGF-1 & Overexpression protective in vivo, delayed onset and progression and extended lifespan in ALS mice & [91] & [4] \\
IGF-2 & Overexpression protective in vitro and in vivo, extended lifespan in ALS mice & [9] & [173] \\
Parvalbumin & Overexpression protective in vivo, delayed onset and extended lifespan in ALS mice & References \\
Glur2 & Overexpression protective in vivo, delayed onset and extended lifespan in ALS mice & [8] \\
\hline Spinal enriched & Outcome & Overexpression caused ALS-like disease with MN loss & \\
\hline Peripherin & Mutant dynein (loss-of-function) extended survival of SOD1 G93A mice, but not other SOD1 mutant mice & [83] \\
Dynein & Suppression extended lifespan, overexpression accelerated denervation of FF muscle & [90] \\
MMP9 & &
\end{tabular}

[4, 33, 73]. Parvalbumin has previously been shown to be protective in ALS [180], but cannot fully explain differential MN vulnerability as it is also highly expressed in vulnerable spinal MNs. There is also great variability in the parvalbumin protein levels among OMNs, arguing against it being a main effector of neuronal resistance [33]. Differences in inhibitory synaptic transmission, mediated by glycine and GABA neurotransmission, could in part underlie the differential vulnerability of oculomotor, hypoglossal and spinal MNs. We and others have shown that Gabra1 is preferentially expressed in OMNs in rodent and control patient tissues [18, 33, 114]. We also demonstrated that Gabral remains preferential to OMNs in end-stage ALS patients indicating that Gabra1 could be a candidate for MN resistance [33]. Particularly compelling was the finding of a preferential presence of IGF-2 in OMNs in mouse and man in control and ALS [4, 73]. IGFs are known MN survival factors [49, 165] and viral delivery of IGF-1 to SOD $1^{\mathrm{G} 93 \mathrm{~A}}$ mice is protective [91]. We, therefore, inferred that IGF-2 could play a role in oculomotor resistance in ALS. This was further supported by the selective expression of the IGF-1 receptor, which mediates survival upon IGF-1/2 binding, on OMNs and extraocular muscles [4]. We also demonstrated that IGF-2 was protective across MNDs, improving survival of induced pluripotent stem cell-derived spinal MNs from both ALS and SMA patients. Viral delivery of IGF-2 to MNs of SOD $1^{\mathrm{G} 93 \mathrm{~A}}$ mice extended their lifespan with $10 \%$, preserved $\mathrm{MN}$ somas and induced axonal regeneration [4].

A microarray analysis of OMNs and $\mathrm{MNs}$ of the Onuf's nucleus (both resistant to degeneration in ALS) and spinal MNs isolated from P7 mouse tissues identified 18 genes with more than tenfold difference in expression between the resistant and vulnerable MN groups. Seven of these mRNAs were confirmed using in situ hybridization and showed that Sema3e was enriched in OMNs while Npr3, Egln3, Mmp9, Trhr, Hsd17b2 and Nts were enriched in spinal MNs. It was subsequently demonstrated that ablation or reduction of MMP9 delayed muscle denervation and prolonged survival of transgenic mice. Selective introduction of MMP9 into mice was elegantly shown to be sufficient to induce degeneration of fast MNs, confirming the detrimental role of this metalloproteinase [90].

These studies demonstrate that gene/protein expression analysis of MNs with differential susceptibility to degeneration can be used to identify candidates that protect vulnerable MNs. It also shows that neuronal vulnerability is governed both by a lack of certain intrinsic beneficial factors, as well as the presence of detrimental molecules (see Table 1). 


\section{Box 2: Spinal motor unit subtypes}

Extrafusal muscle fibres are those responsible for contraction and movement generation. These are innervated by $\alpha$-MNs. The intrafusal muscle fibres, involved in proprioception, are innervated by smaller $\gamma$-MNs and sensory neurons.

The combination of a MN and all muscle fibres it innervates is known as the motor unit, the smallest functional unit of contractile force. These motor units are subdivided in 3 main classes, based on properties of the muscle fibres. Additionally, these muscle fibres have their own typing classification, which is linked to their myosin heavy chain (MHC) subtype expression [23].

- $\quad$ Fast-twitch, fast-fatigable (FF)

Glycolytic muscle fibres comprised of MHC type IIb (MYH4), sometimes combined with IIx (MYH1). These generate strong contractions but are fatigued rapidly. Innervated by fast-firing MNs. One MN in an FF motor unit typically innervates (far) over 300 muscle fibres, reaching up to 2,000 in the big muscles of the limbs [25]. Molecular markers for FF MNs include MMP9, DLK1 and the alpha3 subunit of the sodium-potassium-ATPase [90, 133, 156].

- $\quad$ Fast-twitch, fatigue-resistant (FR):

Comprised of MHC type IIa (MYH2) muscle fibres with mixed glycolytic and oxidative energy metabolism. They generate strong contractions, albeit not as strong as type IIb fibres. The amount of innervated muscle fibres in one FR motor unit lies in between FF and S motor units, usually ranging around several hundreds.

- $\quad$ Slow-twitch, fatigue-resistant (S):

Largely oxidative (MHC type I; MYH7) muscle fibres that generate relatively weak contractions, but are not fatigued, even after one hour of continuous stimulation. Generally, (far) less than 200 muscle fibres are innervated by one MN [24]. The S-type MNs are also characterised by their higher excitability and slower axonal conduction velocity compared to the FF and FR subtypes. Morphologically, they have on average fewer first-order dendrites and less complex dendritic trees [22]. Osteopontin, SV2A, SIL1 and the alphal subunit of the $\mathrm{Na}^{+} / \mathrm{K}^{+}$ATPase have been described as markers for slow MNs [31, $51,132,156]$.

Since S motor units are not readily fatigable, they are present in muscles that require almost constant tone, such as those required for posture maintenance. These slow motor units are used for up to $35 \%$ of a daily period while the fastest $\mathrm{MN}$ types are used less than $0.2 \%$ of the day, only during exercise bursts [77]. Thus, there is a clear correlation between activity and resistance.

\section{Differential vulnerability between spinal motor units}

Skeletal muscle fibres can be categorised based on their contractile properties. Type I fibres are characterised by mainly oxidative metabolism and a slow-twitch and fatigue-resistant phenotype. Type IIb and IIx muscle fibres use glycolysis as their main energy source and display fast-twitch and fast-fatigable properties. Type IIa fibres form an intermediate class of fast-twitch fibres that retain a level of oxidative capacity.

These subsets of fibres are innervated by distinct $\alpha-\mathrm{MN}$ populations, giving rise to three subsets of motor units (see Box 2). Type I fibres form slow (S) motor units, type IIa fibres form fast-twitch fatigue-resistant (FR) motor units and type IIb fibres fast-twitch fast-fatigable (FF) motor units. All fibre types are often present within one muscle, innervated by their corresponding MNs. However, the ratio between slow and fast fibre types varies between muscles, so as to suit each muscle's function.

In ALS, as demonstrated in the $\mathrm{SOD} 1^{\mathrm{G} 93 \mathrm{~A}}$ mouse model, hind limb muscles containing a high percentage (>90\%) of fast-twitch type II fibres (medial gastrocnemius, tibialis anterior and extensor digitorum longus) have decreased contractile force before slow-twitch muscles like the soleus are affected. Moreover, motor unit 
loss was observed at 40 days of age in the fast-twitch muscles. In the soleus muscle, which contains 50\% slowtwitch fibres, this loss only became apparent at 90 days of age [74]. This corresponds to other findings showing that MNs innervating type IIb fibres degenerate before type IIa and type I fibres are affected [55, 147, 185].

\section{Electrophysiological properties of fast and slow motor neurons}

The exact aetiology for the selective vulnerability of FF MNs is still unknown, although several hypotheses attempt to explain the difference. The MN subtypes themselves differ first and foremost in their firing rate, hence their naming. The after-hyperpolarization (AHP) latency following an action potential is shorter in FF MNs, allowing for a faster firing rate compared to $\mathrm{S}$ MNs [57]. Based on electrophysiological characteristics, lumbar MNs in the SOD1 $1^{\mathrm{G} 85 \mathrm{R}}$ mouse could be clustered into four groups. MN clusters innervating the soleus displayed a slower firing rate compared to those innervating the more fast-twitch tibialis anterior muscle. Motor neuron somas of the fastest firing cluster were hyperpolarized at 2-3 months of age and were subsequently no longer detectable at 4 months of age, at which point the mice had developed motor impairment. Moreover, the number of intracellular aggregations was increased in the MN pool innervating the tibialis anterior [67]. This suggests a disease time course where hyperpolarization of MNs and subsequent intracellular aggregate formation precede muscle denervation and ultimately neuronal cell death, with initiation in the fast firing MNs.

Secondly, the input resistance and therefore intrinsic excitability differs between MN subtypes [35]. Highly excitable $\mathrm{S}$ MNs are depolarized most rapidly, classically because of their smaller size compared to the larger FF MNs (size principle) [76, 122]. In terms of size, the fast MNs have larger dendritic trees and axon diameters, and therefore, a $>20 \%$ larger membrane surface compared to $S$ MNs. Within each subpopulation, there is great variability in soma sizes but on average S, FR and FF MN soma sizes are not significantly different (Fig. 4) [22, 35, 93, 185]. Consequently, a recent study in mice could not separate differentially firing MN clusters based on soma size and morphology, again demonstrating that FF and S MN soma sizes are similar [67]. Notably, size scaling alone cannot fully explain the different input resistances postnatally [93], whereas it can in embryonic MNs [118]. This indicates that passive membrane properties differ between FF and $\mathrm{S}$ MNs. It has been reported that the remaining spinal MNs in end-stage ALS patients have, on average, smaller soma diameters compared to unaffected individuals [92]. This could be interpreted as a selective resistance by smaller
MNs. However, these results could also indicate pathological shrinkage and morphological changes in remaining MNs [95, 96], or be due to the inclusion of small $\gamma$ MNs in the quantification.

The higher excitability of S MNs has classically been hypothesized to confer resistance to degeneration in the presymptomatic stage of disease. This is consistent with that resistant OMNs are more excitable than both $\mathrm{S}$ and FF spinal MNs (see Box 1). Indeed, increasing the excitability of FF MNs presymptomatically by AMPA receptor stimulation and subsequent cation influx reversed the accumulation of misfolded SOD1 protein and protected against cell pathology. On the other hand, partially blocking MN excitability promoted misfolded SOD1 aggregation, although ER stress was reduced, possibly due to reduced intracellular calcium levels [159]. Misfolded SOD1 was later shown to bind to the $\alpha 3$ subunit of the $\mathrm{Na}^{+} / \mathrm{K}^{+}$ATPase, which was selectively expressed on FF MNs, providing more evidence on the direct interaction between misfolded SOD1 and membrane potential regulation [156].

Exactly why intrinsic hyperexcitability can be protective prior to symptom onset, whereas in later disease stages this process appears to precede and possibly induce MN degeneration is currently unclear. Conflicting reports have further complicated the view on hyperexcitability in relation to degeneration.

Challenging the view that hyperexcitability can be protective in early disease stages, mutant SOD1 mice lacking the ER bound Sigma-1 receptor (S1R) displayed higher excitability and an increased number of action potentials, but also displayed exacerbated disease progression [120]. This implies a modulatory role for S1R in cell excitability and implies that hyperexcitability is certainly not per definition beneficial. It was also proposed that hyperexcitability represents a compensatory mechanism to cope with the disease process itself, which would then be characterised by hypoexcitability. In mouse trigeminal motor units a hyperexcitable shift was observed in the FF MN pool. However, a subset of S MNs actually displayed a hypoexcitable shift [184]. Possibly, FF MNs cope in an aberrant way, since overcompensation towards hyperexcitability induces excessive calcium influx and subsequent ER stress and cell damage.

Hyperexcitability of MNs in ALS has been shown in vitro and in vivo $[87,99,118,186]$. However, it has been reported that if any shifts are observed at all, they point towards overall hypoexcitability, irrespective of MN subtype [39]. Here, it was speculated that the reason for differential MN vulnerability lies in the ratio of excitatory versus inhibitory synapses on a neuron. As this ratio is larger for fast firing MNs, these could possibly be more sensitive to excitotoxicity. In contrast, another study observed presymptomatic hyperexcitability specific to S MNs [107]. 

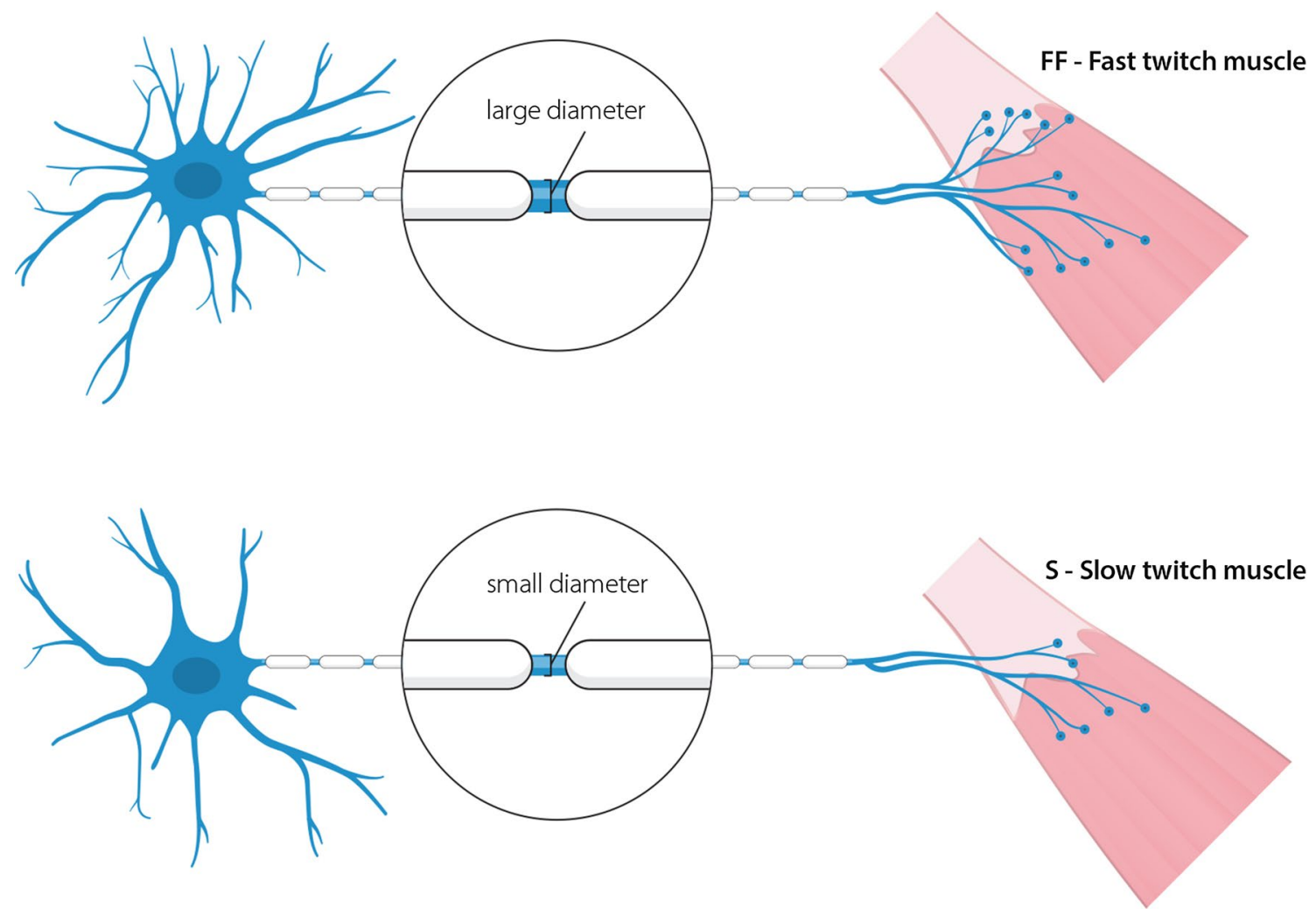

Fig. 4 Subtypes of spinal motor neurons. FF (fast-twitch, fast-fatigable) and $S$ (slow-twitch) are the two extremes of spinal motor neurons. FF motor neurons have bigger and more complex dendritic trees and project with larger calibre axons. FF motor neurons innervate a

This indicates that there is, as of yet, no consensus view on the presence and role of hyperexcitability in ALS.

\section{Molecular characteristics of fast and slow motor neurons}

On the molecular level, several candidates have been proposed to either promote degeneration of fast MNs or increase resilience in slow MNs. Matrix metalloproteinase-9 (MMP9) was proposed as a vulnerability factor. MMP9 was shown to be expressed selectively in the fast MNs prior to onset of disease in mice, and was suggested to drive ER stress, leading to neuronal degeneration [90]. However, others observed similar MMP9 levels across MN subtypes, based on immunohistochemical observations [67]. On the muscle side, MMP9 expression was shown to be selectively present in ALS-affected muscles, while undetectable in unaffected muscle from ALS patients and controls. However, MMP9 expression was not restricted to a specific fibre type [162]. In ALS patients, MMP9 was observed only in a subset of MNs, although it remains to be demonstrated whether these are FF MNs. MMP9 was also large number of endplates and are thus more involved in high-force movements. S motor neurons are more finely structured and are more suited to their function in slow movements and posture maintenance

found in serum [12, 109], but could not be detected in CSF [12]. Reduction of MMP9 levels through either pharmacological inhibition or genetic ablation improved lifespan of mutant SOD1 mice [90, 94, 113].

Conversely, the co-chaperone protein SIL1 was shown to be highly expressed in the resistant $\mathrm{S}$ MNs, while being progressively reduced during disease in FF MNs. Expression of SIL1 appeared to be modulated by excitation of the neuron. Overexcitation with AMPA increased SIL1 mRNA and protein levels. Moreover, experimental reduction of SIL1 expression in the slow-progressing SOD $1^{\mathrm{G} 93 \mathrm{~A}}$ mouse model increased ER stress and decreased survival in a dosedependent manner. Vice versa, overexpression of SIL1 in spinal MNs led to an increase in lifespan [51]. Calreticulin (CRT), another ER chaperone protein, shows a similar subtype-specific pattern of expression. During disease progression CRT levels were reduced solely in the FF MNs, resulting in exacerbation of the Fas/FasL (Fas ligand) cell death pathway [10]. This MN specific cell death pathway results in ER stress due to nitric oxide generation and caspase- 8 activation with subsequent apoptosis. Heterozygous loss of CRT in the SOD $1{ }^{\mathrm{G} 93 \mathrm{~A}}$ mouse resulted in accelerated 
denervation of specifically fast-twitch muscle fibres in the tibialis anterior during early disease stages (P45-P55). However, no differences in motor behaviour, motor neuron number or lifespan were evident compared to SOD $1^{\mathrm{G} 93 \mathrm{~A}}$ mice with normal levels of CRT, indicating that CRT has a role in the modulation of the early peak of ER stress [11].

\section{ER stress and calcium toxicity}

As discussed before, there is a tight link between the differentially expressed genes in S and FF MNs and ER stress. Cellular ER stress is a commonly described molecular mechanism in MNs in several mouse models of ALS, as well as in patient tissue [104]. The cellular coping mechanism for ER stress is the unfolded protein response (UPR). The UPR involves sequestering of chaperone proteins, e.g. SIL1 and CRT, to promote correct protein folding and $\mathrm{Ca}^{2+}$ balance within the cell and within the ER. If correct folding of a protein cannot be achieved, it is typically ubiquitinated and thereby marked for degradation by the proteasome complex. Aberrant function of the UPR can interfere with mitochondrial function and ultimately lead to cell death. It was demonstrated that gastrocnemius-innervating MNs (presumed FF) display earlier signs of ER stress compared to soleus-innervating MNs (presumed FR and S). However, a sharp increase in ER stress and a fully activated UPR was found only in the presumed FF MNs just prior to their degeneration [158].

A correct intracellular $\mathrm{Ca}^{2+}$ level is crucial for $\mathrm{MN}$ function. Regulation of the intracellular $\mathrm{Ca}^{2+}$ concentration must therefore be tightly controlled. The presence of $\mathrm{Ca}^{2+}$ permeable AMPA receptors on MNs, and their lower intrinsic $\mathrm{Ca}^{2+}$ buffering capacity provide clues to why ER stress can be so devastating to these cells in particular [65, 181]. Additionally, in spinal MNs, mitochondria play a large role in $\mathrm{Ca}^{2+}$ buffering, increasing the risk of metabolic disturbances under excitotoxic circumstances [65]. An estimated 1/3rd of AMPA receptors expressed by spinal MNs lack the edited glutamate receptor subunit 2 (GluR2), making these channels permeable to $\mathrm{Ca}^{2+}$ [64]. Strangely, however, GluR2 comprises nearly $2 / 3$ rd of all GluR subunits in these neurons, at both transcript and protein level. This indicates that assembly of subunits into functional AMPA receptors occurs in a regulated fashion, since random assembly would predict that $<3 \%$ of AMPA receptors lack GluR2 [64]. In light of selective vulnerability, no difference at the GluR2 transcript level was observed between resistant OMNs and vulnerable hypoglossal neurons in healthy rats [103]. However, in post-mortem human tissue, GLUR2 was enriched in OMNs compared to spinal MNs [18]. While in ALS total GluR2 transcript levels in the spinal cord did not change, posttranscriptional editing failed in almost half of all transcripts, leading to an increase in $\mathrm{Ca}^{2+}$ permeable channels [100]. Changes in GluR2 levels in OMNs during disease progression were not investigated. The decrease of properly edited spinal GluR2 proteins and the resulting increase in $\mathrm{Ca}^{2+}$ permeability accelerated disease progression in transgenic animals with deficits in this GluR2 mRNA editing [78]. As GluR2 editing changes were not investigated in OMNs in disease, it was hypothesized that these neurons might retain resistance against excitotoxicity. Indeed, it has been shown that OMNs display a reduced inward $\mathrm{Ca}^{2+}$ current through AMPA receptors, providing protection against excitotoxicity [18].

Moreover, the intrinsic $\mathrm{Ca}^{2+}$ buffering capacity of OMNs is higher compared to spinal MNs [181]. Expression of the $\mathrm{Ca}^{2+}$ binding protein calbindin-D28k has been observed to be restricted to resistant OMNs in ALS [3]. It has also been implied in selective neuroprotection in Parkinson's [46] and Alzheimer's disease [149]. However, parvalbumin, another $\mathrm{Ca}^{2+}$ buffering protein, also stated to be selectively expressed in a pattern similar to calbindin-D28k [3] was recently shown to be present in vulnerable spinal MNs as well. Thus, parvalbumin is likely not the sole contributor to selective MN pool resistance [33]. Nonetheless, overexpression of parvalbumin increased the lifespan of ALS mice [9].

\section{Genetic disease modifiers}

The average survival of ALS patients from time of diagnosis is $3-5$ years, but there is a large variability in disease duration, ranging from months to decades, where $10 \%$ of patients live for 10 years or more. Notably, the onset and survival among affected family members with the same gene mutation is highly variable [53, 97]. Also in animal models of ALS, based on SOD1 mutations, it has become evident that the genetic background influences disease duration [75, 135]. These facts point to additional genetic factors playing an important role in modifying disease onset and progression [2, 75]. Such genetic disease modifiers could act both cell intrinsically in MNs or cell extrinsically in, e.g., astrocytes, microglia, oligodendrocytes, Schwann cells and T lymphocytes, all implicated in disease [151].

\section{Atf3, EphA4 and the capacity for motor axon regeneration}

In ALS, some MNs appear to compensate for the loss of their neighbours and sprout to re-innervate denervated muscle fibres $[13,52,55,160]$. For example, synaptic 
a

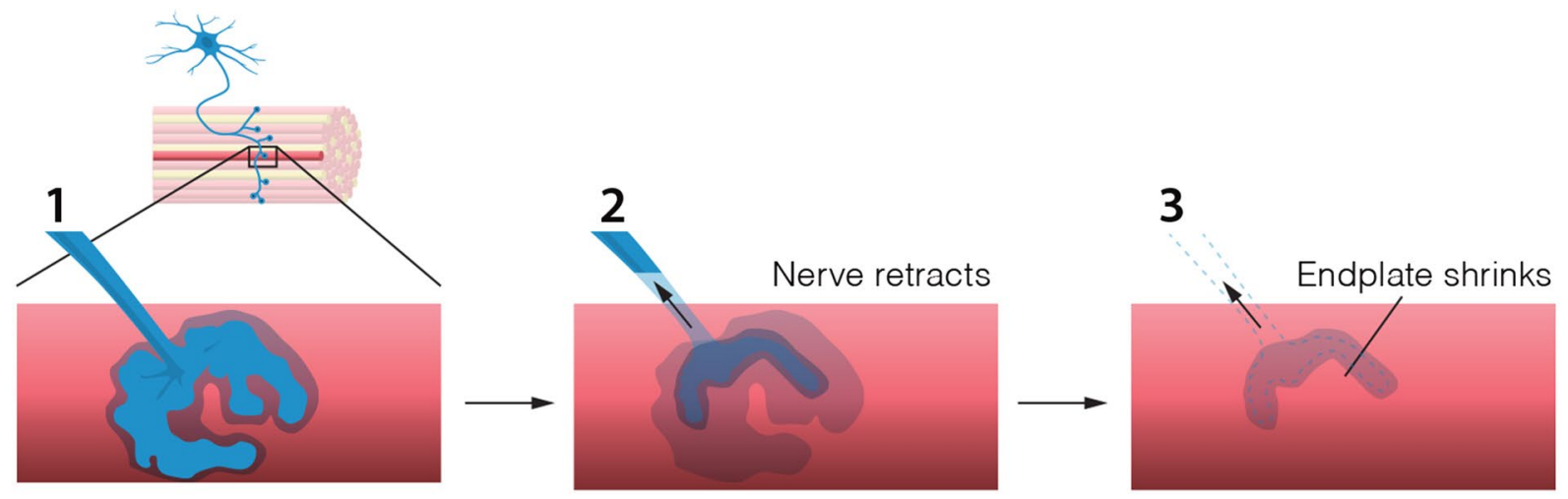

b

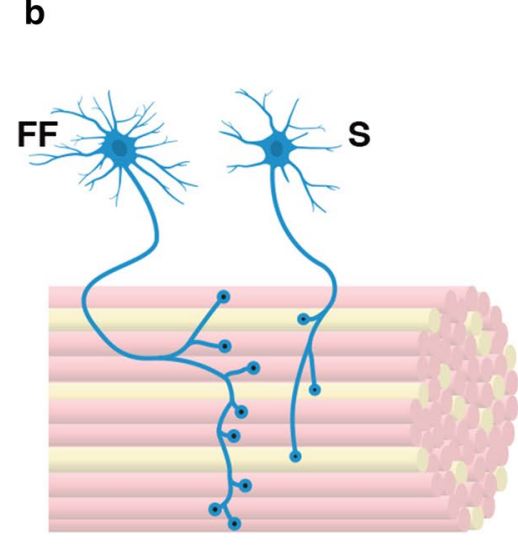

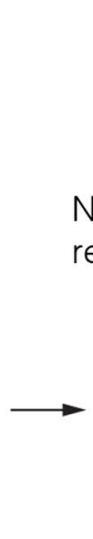

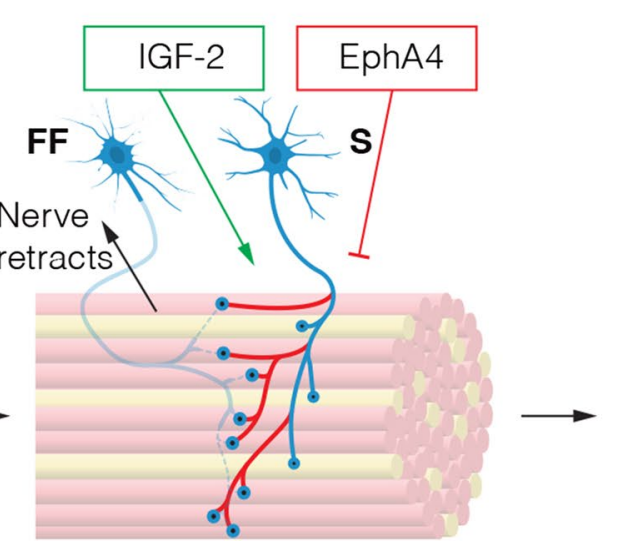

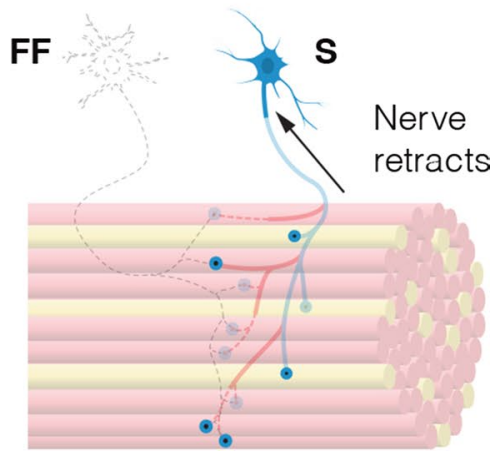

Fig. 5 Motor neuron degeneration in ALS. a A dying motor neuron retracts its axon from the neuromuscular junction. The axon continues to die back towards the soma. Meanwhile the endplate on the muscle fibre dissolves and shrinks as acetylcholine receptors are internalised and removed. b FF motor neurons are the most vulnerable among spinal motors. S motor neurons can temporarily com- pensate for the loss of FF motor neurons by axonal sprouting and re-innervation of denervated endplates. Overexpression of EphA4 can reduce this effect, while overexpression of IGF-2 stimulates re-innervation, causing ALS mice to live longer. Ultimately, however, also S motor neurons die back and leave the muscle denervated sprouting of hypoglossal $\mathrm{MNs}$ in $\mathrm{SOD} 1^{\mathrm{G} 93 \mathrm{~A}}$ mice was shown to increase the uptake and retrograde transport of viral particles injected into the tongue muscle compared to controls [126]. This correlates with our work showing relatively limited NMJ denervation in the exterior portion of the tongue in the SOD1 ${ }^{\mathrm{G} 93 \mathrm{~A}}$ mouse model [34]. Slow motor units display the highest plasticity and capacity for sprouting [55]. Motor units appear to possess either a degenerative or a regenerative phenotype, with the regenerative motor units initially compensating for NMJ denervation [160] (Fig. 5).

Stimulation of the sprouting capacity of $\mathrm{MNs}$ is thought to improve muscle innervation and function of SOD $1^{\mathrm{G} 93 \mathrm{~A}}$ mice. Hence, overexpression of activating transcription factor 3 (ATF3), which enhances nerve regeneration, led to maintenance of sprouting capacity in SOD1 ${ }^{\mathrm{G} 93 \mathrm{~A}}$ mice up to P120. Disease onset was delayed moderately, but disease progression was not influenced [163]. Although ATF3 overexpression significantly increased muscle innervation at P120, similar to levels in P60 presymptomatic SOD1 ${ }^{\mathrm{G} 93 \mathrm{~A}}$ animals, it did not restore muscle strength to the same extent. This implies that a number of the re-innervated NMJs did not reach complete functionality [163].

Conversely, ephrin receptor A4 (EphA4) expression in MNs impaired NMJ re-innervation (Fig. 5). Blood samples of ALS patients showed an inverse correlation between EPHA4 levels and age of disease onset. To test whether a reduction in EphA4 levels was beneficial for axonal regeneration, SOD $1^{\mathrm{G} 93 \mathrm{~A}}$ mice were crossed with mice harbouring a heterozygous deletion of the EphA4 gene. These mice showed extended survival by 2 weeks and NMJ innervation was increased at late-symptomatic stages [182]. Interestingly, knockdown of EphA4 also rescued axonopathy induced by mutations in TDP-43, and loss of SMN1, the gene causative for SMA. This indicates cross disease relevance for EphA4 in disease modulation [182]. 


\section{PGC-1 $\alpha$ and the modulation of muscle fibre type}

The peroxisome proliferator-activated receptor gamma coactivator 1-alpha (PGC-1 $\alpha$ ), a transcriptional coactivator that regulates cellular responses to meet metabolic demands, is a suggested disease modifier in ALS. PGC- $1 \alpha$ drives the formation of type I (slow-twitch) muscle fibres which are significantly higher in mitochondrial content and more dependent on oxidative metabolism than type II (fast-twitch) fibres [110]. Transgenic overexpression of PGC- $1 \alpha$ generates muscle with increased oxidative capacity and resistance to fatigue and the transgenic mice have improved aerobic performance (the "marathon" mouse) [29]. It is well-established that anterograde signals from MNs to muscle influence muscle specification. Consequently, when a motor nerve that normally innervates a fast muscle is forced to innervate immature muscle destined to become slow, the muscle instead acquires electrical properties of a fast muscle and vice versa [21]. Recently, it was shown that overexpression of PGC- $1 \alpha$ in muscle resulted in an increased frequency of $\mathrm{MN}$ terminals positive for the synaptic vesicle protein SV2A, a postnatal marker of slow MNs [31]. This indicates that muscle can influence $M N$ innervation either through inducing selective synapse elimination, sprouting or MN identity conversion through retrograde signals [31]. As S MNs are more resistant to degeneration in ALS than FF MNs and as enhanced mitochondrial activity associated with Type I muscle could be beneficial, the effects of PGC- $1 \alpha$ overexpression in ALS mice have recently been explored. In one study, where PGC- $1 \alpha$ was specifically overexpressed in neurons in SOD $1^{\mathrm{G} 93 \mathrm{~A}}$ mice, motor performance by rotarod was improved in later stages. Survival was increased by 10 days and MN somas were preserved compared to regular SOD1 ${ }^{\mathrm{G} 93 \mathrm{~A}}$ mice [196]. Another study overexpressed PGC- $1 \alpha$ selectively in muscle of SOD $1^{\mathrm{G} 37 \mathrm{R}}$ mice, resulting in improved mitochondrial biogenesis and muscle function, as measured by hind limb endurance, treadmill, running wheel and open field. However, there was no effect on disease onset, length or survival and there was no effect on motor axon or NMJ preservation [36]. Collectively, these studies indicate that PGC-1 $\alpha$ is beneficial for muscle function in ALS, but that musclespecific expression is not sufficient to preserve MNs. This also indicates that expression of PGC- $1 \alpha$ in muscle likely does not result in a full conversion of vulnerable FF MNs into more resistant S MNs.

\section{Non-cell autonomous disease processes}

Selective ablation of mutant SOD1 in cell types other than MNs in transgenic mSOD1 overexpressing mice has revealed that $\mathrm{MN}$ degeneration occurs through an interplay between cell autonomous and non-cell autonomous processes, involving astrocytes, microglia, oligodendrocytes, Schwann cells and T lymphocytes. The initial study, utilizing chimeric mice, showed that MNs surrounded by nonmutant cells survived longer [32], but the specific cell types involved were not identified. Here we give an overview of the cell types at play.

\section{Astrocytes}

Astrocytes are fundamental to synthesis and catabolism of neurotransmitters and amino acids in the central nervous system (CNS). They represent a glycogen reserve and are important in protecting neurons from antioxidants [14, 116]. Astrocytes also control structural and functional plasticity of synapses in the CNS and influence neuronal excitability [166, 178]. However, under influence of activated microglia a subpopulation of astrocytes can become neurotoxic, triggering death of CNS neurons [108]. Removal of mutant SOD1 from astrocytes by crossing loxSOD1 ${ }^{\mathrm{G} 37 \mathrm{R}}$ mice with GFAP-Cre mice resulted in a delayed microglia response and a $15 \%$ increase in lifespan, which was most evident in the late phase of progression. Importantly, removal of mutant SOD1 from astrocytes did not affect disease onset [194]. Astrocytes overexpressing mutant SOD1 appear selectively toxic to MNs in vitro, leaving interneurons unharmed [43, 44]. Notably, not all cells that have high levels of mutant SOD1 are harmful to MNs, as fibroblasts overexpressing mutant SOD1 do not exert toxicity onto ALS MNs [43]. The selective toxicity of astrocytes onto MNs has been used extensively to model ALS-like degeneration in vitro using early postnatal astrocytes [43, 44, 72, 117, 134].

Astrocytes derived from sporadic ALS patients also appear harmful to motor neurons, as shown using astrocytes derived from post-mortem spinal cords [68] and through direct conversion of patient fibroblasts into astrocytes [125].

It is not yet clear if MNs that are relatively resistant to degeneration in ALS are less susceptible to toxic astrocytes or if there is less neuro-inflammation around these resistant cells throughout disease. S and FF spinal MNs are located in close proximity to each other and thus likely have equal exposure to detrimental astrocytes. Therefore, cell-intrinsic differences are more likely the reason for the difference in their demise. It is not known if resistant MNs of Onuf's nucleus and oculomotor nucleus show differential vulnerability to astrocyte toxicity and/or if the astrocytes surrounding these nuclei are distinct in their response to ALS. Astrocytes within the ventral spinal cord have positionally distinct identities determined by Hox transcription factors [80]. As Hox genes pattern the anterior-posterior axis of the developing embryo, it is likely that rostral astrocytes have identities distinct from caudal astrocytes, just as the MNs 
they surround do. Therefore, it is possible that astrocytes in the midbrain could show a different response to ALS-causing mutations than spinal cord astrocytes. However, this remains to be investigated. Furthermore, astrocytes in the ventral spinal cord can be distinguished from astrocytes in the dorsal spinal cord through a number of markers, in particular Sema3a, which is required for proper organisation of MN circuits. Loss of Sema3a in these astrocytes leads to selective degeneration of alpha but not gamma MNs [80, 130]. It remains to be investigated if Sema3a expression is altered in astrocytes in ALS and also if Sema3a expression is regulated along the anterior-posterior axis of the CNS.

\section{Microglia}

Microglia are resident immune cells of the brain and spinal cord. They arise from primitive macrophages from the yolk sac and populate the CNS during early development (reviewed in [59]). Microglia are an important component of the inflammatory response to injury and pathogens, and they also influence synapse formation and neurogenesis [161]. Microglia are activated early during disease pathogenesis in ALS [69]. Genetic removal of mutant SOD1 from microglia had no effect on disease initiation or early disease, but significantly slowed later disease progression resulting in an increased mean lifespan of 99 days (a 30\% increase in lifespan) [16]. Moreover, adult microglia overexpressing mutant SOD $1^{\mathrm{G} 93 \mathrm{~A}}$ were toxic to wildtype mESC-derived Hb9-GFP MNs. Notably, neonatal microglia were not found to be toxic to MNs, indicating that the microglia toxicity is acquired and not innate [54]. It remains to be investigated if adult MNs are more susceptible to microglia than the embryonic or early postnatal MNs used in all current and past in vitro studies. This could be technically challenging, but potentially investigated using inducible MNs generated by direct reprogramming of fibroblasts from an aged person, as this procedure should allow generated neurons to retain the age of the donor [123]. Mechanistically, it appears that NF- $\kappa B$ activation within microglia plays a role in $\mathrm{MN}$ death. Deletion of NF- $\kappa \mathrm{B}$ signalling from microglia extended disease progression in SOD $1^{\mathrm{G} 93 \mathrm{~A}}$ mice without an effect on disease onset. Consequently, survival was improved by 20 days (a 14\% increase) [54]. The authors found no difference in toxicity between brain and spinal cord microglia, implying that these cells lack positional difference in toxicity/activation capacity or that such differences cannot be detected due to the exceptional migratory properties of microglia along the rostro-caudal axis of the animal. Removal of a cysteine/glutamate antiporter, $\mathrm{xC}$, which is enriched on microglia and increased in ALS, decreased glutamate release and the production of nitric oxide, TNF alpha and IL- 6 by microglia. Functionally, removal of $\mathrm{xC}$ in
SOD $1^{\mathrm{G} 37 \mathrm{R}}$ mice resulted in an earlier onset of disease but slowed the progression [124]. Thus, $\mathrm{xC}$ is a mediator of microglial function which could potentially be modulated after onset of symptoms to prolong lifespan of patients.

\section{Oligodendrocytes}

Oligodendrocytes, which are derived from oligodendrocyte precursor cells (OPCs), myelinate axons in the CNS. They can extend processes to form myelin sheaths around up to 50 neurons and provide crucial metabolic support to these. The monocarboxylate transporter 1 (MCT1 or SLC16A1), which transports lactate, pyruvate and ketone bodies, is highly expressed within oligodendrocytes [150] and down-regulation of this transporter resulted in axon damage and neuronal loss in animal models. Furthermore, ALS patients appeared to show reduced levels of this transporter, indicating the oligodendrocytes could be less metabolically supportive in ALS [106]. Recent findings demonstrate that ALS patients and transgenic ALS mice display demyelination in grey matter regions of motor cortex and spinal cord caused by a progressive degeneration of oligodendrocytes [89]. Simultaneously there is extensive recruitment and proliferation of $\mathrm{NG}^{+}{ }^{+} \mathrm{OPC}$ in fALS mice [88, 89], similar to that seen in relapse-remitting multiple sclerosis (MS). Nevertheless, while new oligodendrocytes constantly differentiated from OPCs in the fALS mice, they failed to mature. When mutant SOD1 was removed from oligodendrocytes, disease onset was delayed and the survival of fALS mice was prolonged, suggesting that impaired oligodendrocyte function contributes to MN loss in SOD1-related ALS [89]. Whether this holds true for sALS and other forms of fALS remains to be investigated.

\section{Schwann cells}

Schwann cells originate from neural crest cells and are the myelinating glia of the peripheral nervous system. In contrast to oligodendrocytes each Schwann cell myelinates only one axon. Individual Schwann cells myelinate approximately $100 \mu \mathrm{m}$ of an axon. Thus, a one meter long motor axon can be covered by up to 10,000 individual Schwann cells. During development, Schwann cells are crucial for MN survival. Furthermore, neuron-derived factors guide differentiation and survival of Schwann cells along the axons [193]. In ALS, where motor axons retract and regenerate, fibres in the ventral root show segmental demyelination and remyelination to an extent greater than in control patients, indicating Schwann cell involvement [70]. If interaction between Schwann cells and motor axons could be made more efficient, 
for example by modulating neuregulin-1 (Nrg1) levels [172], it could be possible to improve regeneration and potentially improve function in ALS. Indeed, viral mediated delivery of $\mathrm{Nrg} 1$ into the gastrocnemius muscle of SOD $1^{\mathrm{G} 93 \mathrm{~A}}$ mice improved local collateral sprouting of motor axons [115].

While genetic reduction of mutant SOD1 from astrocytes, microglia and oligodendrocytes can confer protection to MNs (see sections above), reduction of mutant SOD $1^{\text {G37R }}$ within Schwann cells did not affect disease onset, but unexpectedly reduced survival by accelerating disease progression of ALS mice. Here, end-stage was reached on average 42 days earlier, reducing the mean survival by $10 \%$ [112]. Mutant SOD1 was decreased both in Schwann cells surrounding peripheral axons and in terminal Schwann cells at the NMJ. The reduction in mutant SOD1 was accompanied by a selective decrease in IGF-1 in the nerves [112]. This reduction in IGF levels would reduce the capacity of MNs to regenerate and form new NMJs with denervated muscle which is a process that prolongs the disease progression phase. This is exemplified by the inverse relationship between EphA4 and duration of disease in ALS patients [182] and with the successful IGF$1 / 2$ treatments in mice $[4,91]$. However, the removal of mutant SOD1 from Schwann cells does not, per definition, exacerbate disease. In the SOD $1^{\mathrm{G} 85 \mathrm{R}}$ model knock-down of mutant SOD1 in Schwann cells delayed disease onset and extended survival slightly [188]. This SOD1 mutant retains no enzymatic activity, unlike the SOD1 ${ }^{\mathrm{G} 37 \mathrm{R}}$. Probably the increased dismutase activity in the SOD $1^{\mathrm{G} 37 \mathrm{R}}$ mutant partly ameliorates the toxic effects of the mutation in Schwann cells. Conversely, in the SOD1 ${ }^{\mathrm{G} 85 \mathrm{R}}$ model Schwann cells are only burdened by the mutation, explaining the beneficial effect upon mutant SOD1 knock-down. Combined, these studies highlight a strong dependence of Schwann cells on dismutase activity.

\section{Muscle}

Nerve cells are produced in excess in the developing nervous system and subsequently compete for the limited amount of survival factors that are secreted by their target cells. Only the cells that receive the appropriate type and level of survival signals are maintained. During normal development, MNs in the lateral motor column undergo apoptosis, in which $40 \%$ of MNs are lost. Increasing the muscle target area by transplantation of a second leg bud can partially inhibit the MN loss, demonstrating the importance of muscle in the normal survival of MNs [81]. Retraction of the presynaptic motor terminal from muscle endplates is an early event in ALS. Nonetheless, the involvement of muscle in ALS disease onset and progression is highly debated. Several studies have investigated the pathological consequences of modulating the levels of mutant SOD1 in muscle with opposing conclusions drawn from the data received. In one study, mutant $\mathrm{SOD} 1^{\mathrm{G} 93 \mathrm{~A}}$ was reduced in $\mathrm{MNs}$ by $\mathrm{AAV}$-mediated siRNA delivery to muscle and retrograde transport to $\mathrm{MN}$ somas, resulting in functional improvement. In comparison, muscle-restricted reduction of mutant SOD1 to $50 \%$ using lentivirus-mediated siRNA, which did not transport retrogradely to MNs, showed no effect [127]. Thus, either muscle is not a primary target in ALS, or reducing mutant SOD1 in this tissue to $50 \%$ was not sufficient to reduce toxicity.

Another study addressed the issue of mutant SOD1 action in muscle by selective overexpression of $\mathrm{SOD} 1^{\mathrm{G} 93 \mathrm{~A}}$ in muscle. These mice developed progressive muscle atrophy and mitochondrial dysfunction. Interestingly, PGC- $1 \alpha$ expression was induced by mutant SOD1 and consequently a switch to more oxidative fibres was seen. Even a mildlevel of overexpression of mutant SOD1 had a negative effect on muscle morphology indicating that the decrease in SOD1 levels in muscle accomplished in the study by Miller and colleagues [127] might not have been sufficient. However, mutant SOD1 levels in muscle alone did not appear sufficient to induce $\mathrm{MN}$ degeneration [45]. This would indicate that while mutant SOD1 can induce pathology in muscle, it is not sufficient to drive disease systemically.

A more recent study aimed to analyse the effect of muscle-specific overexpression of both wild-type and mutant SOD1 using the $\alpha$-actin promoter. Rather surprisingly, MN degeneration was seen with both wild-type and mutant SOD1 overexpression [192]. The detrimental effect observed upon wild-type SOD1 overexpression could perhaps be explained by disruption of endogenous gene expression (unrelated to SOD1) in the transgenic mice. However, this remains to be investigated. The neurodegenerative effect upon mutant SOD1 overexpression is likely explained by the promoter used in the study. While $\alpha$-actin is thought of as a musclespecific transcript, in situ hybridization images in Allen Brain Atlas show that MNs also express high levels of $\alpha$-actin (ACTA1), http://mousespinal.brain-map.org/imageseries/ show.html?id=100069897. Thus, SOD1 is highly likely to have been overexpressed in multiple cell types even though this was not detected at the time points analysed.

\section{Conclusion}

While somatic MNs are selectively vulnerable in ALS and degenerate in a retrograde fashion, OMNs are resistant to degeneration and stably innervate their muscle targets throughout disease. In the spinal cord relatively resistant S MNs have the capacity to remodel their connectivity with muscle during early disease and partially 
compensate for the loss of vulnerable FF MNs. Comparative analysis of cell intrinsic properties of these resistant and vulnerable $\mathrm{MN}$ groups has begun to reveal the underlying mechanisms of selective vulnerability, resulting in multiple potential targets for future therapies, some of which appear protective across MNDs. Cells other than MNs contribute to disease initiation and progression in ALS and further investigation could reveal if these also contribute to differential vulnerability among MNs.

Acknowledgements We would like to thank Mattias Karlen for his excellent work in creating the figures for this review. We would also like to thank Staffan Cullheim for very informative and interesting discussions on slow and fast motor neurons. The work in our laboratory is supported by the Swedish Medical Research Council (VR), the Joint Program for Neurodegenerative Diseases (JPND), Åhlénstiftelsen, Birgit Backmark's Donation to ALS research at Karolinska Institutet in memory of Nils and Hans Backmark, ParkinsonFonden, Ulla-Carin Lindquists stiftelse för ALS forskning, NEURO Sweden, Magnus Bergvalls stiftelse and the Strategic Research Area Neuroscience (StratNeuro).

Open Access This article is distributed under the terms of the Creative Commons Attribution 4.0 International License (http://creativecommons.org/licenses/by/4.0/), which permits unrestricted use, distribution, and reproduction in any medium, provided you give appropriate credit to the original author(s) and the source, provide a link to the Creative Commons license, and indicate if changes were made.

\section{References}

1. Abhinav K, Stanton B, Johnston C, Hardstaff J, Orrell R, Howard R, Clarke J, Sakel M, Ampong M, Shaw C (2007) Amyotrophic lateral sclerosis in South-East England: a population-based study. Neuroepidemiology 29:44-48

2. Al-Chalabi A, Andersen PM, Chioza B, Shaw C, Sham PC, Robberecht W, Matthijs G, Camu W, Marklund SL, Forsgren L (1998) Recessive amyotrophic lateral sclerosis families with the D90A SOD1 mutation share a common founder: evidence for a linked protective factor. Hum Mol Genet 7:2045-2050

3. Alexianu ME, Ho BK, Mohamed AH, La Bella V, Smith RG, Appel SH (1994) The role of calcium-binding proteins in selective motoneuron vulnerability in amyotrophic lateral sclerosis. Ann Neurol 36:846-858. doi:10.1002/ ana.410360608

4. Allodi I, Comley L, Nichterwitz S, Nizzardo M, Simone C, Benitez JA, Cao M, Corti S, Hedlund E (2016) Differential neuronal vulnerability identifies IGF-2 as a protective factor in ALS. Sci Rep 6:25960. doi:10.1038/srep25960

5. An T, Shi P, Duan W, Zhang S, Yuan P, Li Z, Wu D, Xu Z, Li C, Guo Y (2014) Oxidative stress and autophagic alteration in brainstem of SOD1-G93A mouse model of ALS. Mol Neurobiol 49:1435-1448. doi:10.1007/s12035-013-8623-3

6. Andersson E, Tryggvason U, Deng Q, Friling S, Alekseenko Z, Robert B, Perlmann T, Ericson J (2006) Identification of intrinsic determinants of midbrain dopamine neurons. Cell 124:393-405. doi:10.1016/j.cell.2005.10.037

7. Atanasio A, Decman V, White D, Ramos M, Ikiz B, Lee HC, Siao CJ, Brydges S, LaRosa E, Bai Y et al (2016) C9orf72 ablation causes immune dysregulation characterized by leukocyte expansion, autoantibody production, and glomerulonephropathy in mice. Sci Rep 6:23204. doi:10.1038/srep23204

8. Beaulieu JM, Nguyen MD, Julien JP (1999) Late onset of motor neurons in mice overexpressing wild-type peripherin. $\mathrm{J}$ Cell Biol 147:531-544

9. Beers DR, Ho BK, Siklos L, Alexianu ME, Mosier DR, Mohamed AH, Otsuka Y, Kozovska ME, McAlhany RE, Smith RG et al (2001) Parvalbumin overexpression alters immune-mediated increases in intracellular calcium, and delays disease onset in a transgenic model of familial amyotrophic lateral sclerosis. J Neurochem 79:499-509

10. Bernard-Marissal N, Moumen A, Sunyach C, Pellegrino C, Dudley K, Henderson CE, Raoul C, Pettmann B (2012) Reduced calreticulin levels link endoplasmic reticulum stress and Fas-triggered cell death in motoneurons vulnerable to ALS. J Neurosci 32:4901-4912

11. Bernard-Marissal N, Sunyach C, Marissal T, Raoul C, Pettmann B (2015) Calreticulin levels determine onset of early muscle denervation by fast motoneurons of ALS model mice. Neurobiol Dis 73:130-136. doi:10.1016/j.nbd.2014.09.009

12. Beuche W, Yushchenko M, Mader M, Maliszewska M, Felgenhauer K, Weber F (2000) Matrix metalloproteinase-9 is elevated in serum of patients with amyotrophic lateral sclerosis. NeuroReport 11:3419-3422

13. Bjornskov EK, Norris FH Jr, Mower-Kuby J (1984) Quantitative axon terminal and end-plate morphology in amyotrophic lateral sclerosis. Arch Neurol 41:527-530

14. Blackburn D, Sargsyan S, Monk PN, Shaw PJ (2009) Astrocyte function and role in motor neuron disease: a future therapeutic target? Glia 57:1251-1264

15. Boeynaems S, Bogaert E, Van Damme P, Van Den Bosch L (2016) Inside out: the role of nucleocytoplasmic transport in ALS and FTLD. Acta Neuropathol 132:159-173. doi:10.1007/s00401-016-1586-5

16. Boillée S, Yamanaka K, Lobsiger CS, Copeland NG, Jenkins NA, Kassiotis G, Kollias G, Cleveland DW (2006) Onset and progression in inherited ALS determined by motor neurons and microglia. Science 312:1389-1392

17. Brettschneider J, Arai K, Del Tredici K, Toledo JB, Robinson JL, Lee EB, Kuwabara S, Shibuya K, Irwin DJ, Fang L et al (2014) TDP-43 pathology and neuronal loss in amyotrophic lateral sclerosis spinal cord. Acta Neuropathol 128:423-437. doi:10.1007/s00401-014-1299-6

18. Brockington A, Ning K, Heath PR, Wood E, Kirby J, Fusi N, Lawrence N, Wharton SB, Ince PG, Shaw PJ (2013) Unravelling the enigma of selective vulnerability in neurodegeneration: motor neurons resistant to degeneration in ALS show distinct gene expression characteristics and decreased susceptibility to excitotoxicity. Acta Neuropathol 125:95-109

19. Brueckner JK, Itkis O, Porter JD (1996) Spatial and temporal patterns of myosin heavy chain expression in developing rat extraocular muscle. J Muscle Res Cell Motil 17:297-312

20. Bruneteau G, Bauché S, Gonzalez de Aguilar JL, Brochier G, Mandjee N, Tanguy ML, Hussain G, Behin A, Khiami F, Sariali E (2015) Endplate denervation correlates with NogoA muscle expression in amyotrophic lateral sclerosis patients. Ann Clin Transl Neurol 2:362-372

21. Buller A, Eccles J, Eccles RM (1960) Interactions between motoneurones and muscles in respect of the characteristic speeds of their responses. J Physiol 150:417-439

22. Burke R, Dum R, Fleshman J, Glenn L, Lev-Tov A, O'Donovan M, Pinter M (1982) An HRP study of the relation between cell size and motor unit type in cat ankle extensor motoneurons. J Comp Neurol 209:17-28 
23. Burke R, Levine D, Zajac F, Tsairis P, Engel W (1971) Mammalian motor units: physiological-histochemical correlation in three types in cat gastrocnemius. Science 174:709-712

24. Burke RE, Levine DN, Tsairis P, Zajac FE 3rd (1973) Physiological types and histochemical profiles in motor units of the cat gastrocnemius. J Physiol 234:723-748

25. Burke RE, Tsairis $P$ (1973) Anatomy and innervation ratios in motor units of cat gastrocnemius. J Physiol 234:749-765

26. Büttner-Ennever JA (2007) Anatomy of the oculomotor system. In: Straube A, Büttner U (eds) Neuro-ophthalmology: neuronal control of eye movements. Karger, Basel

27. Büttner-Ennever JA, Horn AK, Scherberger H, D'Ascanio P (2001) Motoneurons of twitch and nontwitch extraocular muscle fibers in the abducens, trochlear, and oculomotor nuclei of monkeys. J Comp Neurol 438:318-335

28. Caligari M, Godi M, Guglielmetti S, Franchignoni F, Nardone A (2013) Eye tracking communication devices in amyotrophic lateral sclerosis: impact on disability and quality of life. Amyotroph Lateral Scler Front Degener 14:546-552. doi $: 10.3109 / 21678421.2013 .803576$

29. Calvo JA, Daniels TG, Wang X, Paul A, Lin J, Spiegelman BM, Stevenson SC, Rangwala SM (2008) Musclespecific expression of PPARgamma coactivator-1alpha improves exercise performance and increases peak oxygen uptake. J Appl Physiol (1985) 104:1304-1312. doi:10.1152/ japplphysiol.01231.2007

30. Carvalho M, Schwartz MS, Swash M (1995) Involvement of the external anal sphincter in amyotrophic lateral sclerosis. Muscle Nerve 18:848-853. doi:10.1002/mus.880180808

31. Chakkalakal JV, Nishimune H, Ruas JL, Spiegelman BM, Sanes JR (2010) Retrograde influence of muscle fibers on their innervation revealed by a novel marker for slow motoneurons. Development 137:3489-3499

32. Clement A, Nguyen M, Roberts E, Garcia M, Boillee S, Rule M, McMahon A, Doucette W, Siwek D, Ferrante R (2003) Wild-type nonneuronal cells extend survival of SOD1 mutant motor neurons in ALS mice. Science 302:113-117

33. Comley L, Allodi I, Nichterwitz S, Nizzardo M, Simone C, Corti S, Hedlund E (2015) Motor neurons with differential vulnerability to degeneration show distinct protein signatures in health and ALS. Neuroscience 291:216-229. doi:10.1016/j. neuroscience.2015.02.013

34. Comley LH, Nijssen J, Frost-Nylen J, Hedlund E (2016) Crossdisease comparison of amyotrophic lateral sclerosis and spinal muscular atrophy reveals conservation of selective vulnerability but differential neuromuscular junction pathology. J Comp Neurol 524:1424-1442. doi:10.1002/cne.23917

35. Cullheim S, Fleshman J, Glenn L, Burke R (1987) Membrane area and dendritic structure in type-identified triceps surae alpha motoneurons. J Comp Neurol 255:68-81

36. Da Cruz S, Parone PA, Lopes VS, Lillo C, McAlonis-Downes M, Lee SK, Vetto AP, Petrosyan S, Marsala M, Murphy AN (2012) Elevated PGC- $1 \alpha$ activity sustains mitochondrial biogenesis and muscle function without extending survival in a mouse model of inherited ALS. Cell Metab 15:778-786

37. De La Cruz RR, Escudero M, Delgado-Garcia JM (1989) Behaviour of medial rectus motoneurons in the alert cat. Eur $\mathrm{J}$ Neurosci 1:288-295

38. DeJesus-Hernandez M, Mackenzie IR, Boeve BF, Boxer AL, Baker M, Rutherford NJ, Nicholson AM, Finch NA, Flynn H, Adamson J (2011) Expanded GGGGCC hexanucleotide repeat in noncoding region of C9ORF72 causes chromosome 9p-linked FTD and ALS. Neuron 72:245-256

39. Delestrée N, Manuel M, Iglesias C, Elbasiouny SM, Heckman C, Zytnicki D (2014) Adult spinal motoneurones are not hyperexcitable in a mouse model of inherited amyotrophic lateral sclerosis. J Physiol 592:1687-1703

40. Deng Q, Andersson E, Hedlund E, Alekseenko Z, Coppola E, Panman L, Millonig JH, Brunet JF, Ericson J, Perlmann $\mathrm{T}$ (2011) Specific and integrated roles of Lmx1a, Lmx1b and Phox2a in ventral midbrain development. Development 138:3399-3408. doi:10.1242/dev.065482

41. Dengler R, Konstanzer A, Küther G, Hesse S, Wolf W, Strupplerdr A (1990) Amyotrophic lateral sclerosis: macro-EMG and twitch forces of single motor units. Muscle Nerve 13:545-550

42. Dewil M, dela Cruz VF, Van Den Bosch L, Robberecht W (2007) Inhibition of p38 mitogen activated protein kinase activation and mutant SOD1(G93A)-induced motor neuron death. Neurobiol Dis 26:332-341. doi:10.1016/j.nbd.2006.12.023

43. Di Giorgio FP, Boulting GL, Bobrowicz S, Eggan KC (2008) Human embryonic stem cell-derived motor neurons are sensitive to the toxic effect of glial cells carrying an ALS-causing mutation. Cell Stem Cell 3:637-648

44. Di Giorgio FP, Carrasco MA, Siao MC, Maniatis T, Eggan K (2007) Non-cell autonomous effect of glia on motor neurons in an embryonic stem cell-based ALS model. Nat Neurosci 10:608-614

45. Dobrowolny G, Aucello M, Rizzuto E, Beccafico S, Mammucari C, Boncompagni S, Belia S, Wannenes F, Nicoletti C, Del Prete Z et al (2008) Skeletal muscle is a primary target of SOD1G93A-mediated toxicity. Cell Metab 8:425-436. doi:10.1016/j.cmet.2008.09.002

46. Dopeso-Reyes IG, Rico AJ, Roda E, Sierra S, Pignataro D, Lanz M, Sucunza D, Chang-Azancot L, Lanciego JL (2014) Calbindin content and differential vulnerability of midbrain efferent dopaminergic neurons in macaques. Front Neuroanat 8:146. doi:10.3389/fnana.2014.00146

47. Dubreuil V, Hirsch MR, Pattyn A, Brunet JF, Goridis C (2000) The Phox $2 \mathrm{~b}$ transcription factor coordinately regulates neuronal cell cycle exit and identity. Development 127:5191-5201

48. Enoka RM (1995) Morphological features and activation patterns of motor units. J Clin Neurophysiol 12:538-559

49. Eustache I, Seyfritz N, Gueritaud JP (1994) Effects of insulin-like growth factors on organotypic cocultures of embryonic rat brainstem slices and skeletal muscle fibers. Brain Res Dev Brain Res 81:284-292

50. Ferri AL, Lin W, Mavromatakis YE, Wang JC, Sasaki H, Whitsett JA, Ang SL (2007) Foxa1 and Foxa2 regulate multiple phases of midbrain dopaminergic neuron development in a dosage-dependent manner. Development 134:2761-2769. doi: $10.1242 /$ dev.000141

51. Filezac de L'Etang A, Maharjan N, Cordeiro Brana M, Ruegsegger C, Rehmann R, Goswami A, Roos A, Troost D, Schneider BL, Weis J et al (2015) Marinesco-Sjogren syndrome protein SIL1 regulates motor neuron subtype-selective ER stress in ALS. Nat Neurosci 18:227-238. doi:10.1038/ nn. 3903

52. Fischer LR, Culver DG, Tennant P, Davis AA, Wang M, Castellano-Sanchez A, Khan J, Polak MA, Glass JD (2004) Amyotrophic lateral sclerosis is a distal axonopathy: evidence in mice and man. Exp Neurol 185:232-240

53. Fogh I, Rijsdijk F, Andersen PM, Sham PC, Knight J, Neale B, McKenna-Yasek D, Silani V, Brown RH Jr, Powell JF (2007) Age at onset in sod1-mediated amyotrophic lateral sclerosis shows familiality. Neurogenetics 8:235-236

54. Frakes AE, Ferraiuolo L, Haidet-Phillips AM, Schmelzer L, Braun L, Miranda CJ, Ladner KJ, Bevan AK, Foust KD, Godbout JP (2014) Microglia induce motor neuron death via the classical NF- $\mathrm{B}$ pathway in amyotrophic lateral sclerosis. Neuron 81:1009-1023 
55. Frey D, Schneider C, Xu L, Borg J, Spooren W, Caroni P (2000) Early and selective loss of neuromuscular synapse subtypes with low sprouting competence in motoneuron diseases. J Neurosci 20:2534-2542

56. Fuchs AF, Scudder CA, Kaneko CR (1988) Discharge patterns and recruitment order of identified motoneurons and internuclear neurons in the monkey abducens nucleus. J Neurophysiol 60:1874-1895

57. Gardiner PF (1993) Physiological properties of motoneurons innervating different muscle unit types in rat gastrocnemius. $\mathbf{J}$ Neurophysiol 69:1160-1170

58. Genc B, Jara JH, Schultz MC, Manuel M, Stanford MJ, Gautam M, Klessner JL, Sekerkova G, Heller DB, Cox GA et al (2016) Absence of UCHL 1 function leads to selective motor neuropathy. Ann Clin Transl Neurol 3:331-345. doi:10.1002/ acn3.298

59. Ginhoux F, Lim S, Hoeffel G, Low D, Huber T (2013) Origin and differentiation of microglia. Front Cell Neurosci 7:45. doi:10.3389/fncel.2013.00045

60. Gitler AD, Tsuiji H (2016) There has been an awakening: emerging mechanisms of C9orf72 mutations in FTD/ALS. Brain Res 1647:19-29. doi:10.1016/j.brainres.2016.04.004

61. Gizzi M, DiRocco A, Sivak M, Cohen B (1992) Ocular motor function in motor neuron disease. Neurology 42:1037-1046

62. Gould TW, Buss RR, Vinsant S, Prevette D, Sun W, Knudson CM, Milligan CE, Oppenheim RW (2006) Complete dissociation of motor neuron death from motor dysfunction by Bax deletion in a mouse model of ALS. J Neurosci 26:8774-8786. doi:10.1523/jneurosci.2315-06.2006

63. Grant K, Gueritaud JP, Horcholle-Bossavit G, Tyc-Dumont S (1979) Morphological characteristics of lateral rectus motoneurones shown by intracellular injection of HRP. J Physiol (Paris) 75:513-519

64. Greig A, Donevan SD, Mujtaba TJ, Parks TN, Rao MS (2000) Characterization of the AMPA-Activated Receptors Present on Motoneurons. J Neurochem 74:179-191

65. Grosskreutz J, Van Den Bosch L, Keller BU (2010) Calcium dysregulation in amyotrophic lateral sclerosis. Cell Calcium 47:165-174

66. Gueritaud JP, Horcholle-Bossavit G, Jami L, Thiesson D, Tyc-Dumont S (1985) Resistance to glycogen depletion of motor units in the cat rectus lateralis muscle. Exp Brain Res 60:542-550

67. Hadzipasic M, Tahvildari B, Nagy M, Bian M, Horwich AL, McCormick DA (2014) Selective degeneration of a physiological subtype of spinal motor neuron in mice with SOD1-linked ALS. Proc Natl Acad Sci USA 111:16883-16888

68. Haidet-Phillips AM, Hester ME, Miranda CJ, Meyer K, Braun L, Frakes A, Song S, Likhite S, Murtha MJ, Foust KD (2011) Astrocytes from familial and sporadic ALS patients are toxic to motor neurons. Nat Biotechnol 29:824-828

69. Hall ED, Oostveen JA, Gurney ME (1998) Relationship of microglial and astrocytic activation to disease onset and progression in a transgenic model of familial ALS. Glia 23:249-256

70. Hanyu N, Oguchi K, Yanagisawa N, Tsukagoshi H (1982) Degeneration and regeneration of ventral root motor fibers in amyotrophic lateral sclerosis. Morphometric studies of cervical ventral roots. J Neurol Sci 55:99-115

71. Hasan KB, Agarwala S, Ragsdale CW (2010) PHOX2A regulation of oculomotor complex nucleogenesis. Development 137:1205-1213. doi:10.1242/dev.041251

72. Hedlund E, Isacson O (2008) ALS model glia can mediate toxicity to motor neurons derived from human embryonic stem cells. Cell Stem Cell 3:575-576
73. Hedlund E, Karlsson M, Osborn T, Ludwig W, Isacson O (2010) Global gene expression profiling of somatic motor neuron populations with different vulnerability identify molecules and pathways of degeneration and protection. Brain 133:2313-2330

74. Hegedus J, Putman C, Gordon T (2007) Time course of preferential motor unit loss in the SOD1 ${ }^{\mathrm{G} 93 \mathrm{~A}}$ mouse model of amyotrophic lateral sclerosis. Neurobiol Dis 28:154-164

75. Heiman-Patterson TD, Sher RB, Blankenhorn EA, Alexander G, Deitch JS, Kunst CB, Maragakis N, Cox G (2011) Effect of genetic background on phenotype variability in transgenic mouse models of amyotrophic lateral sclerosis: a window of opportunity in the search for genetic modifiers. Amyotroph Lateral Scler 12:79-86

76. Henneman E, Somjen G, Carpenter DO (1965) Excitability and inhibitibility of motoneurons of different sizes. J Neurophysiol 28:599-620

77. Hennig R, Lømo T (1984) Discharge patterns of presumed FF, $\mathrm{FR}$ and $\mathrm{S}$ motor units during normal motor behaviour in the rat. Acta Physiol Scand 121:A28

78. Hideyama T, Yamashita T, Suzuki T, Tsuji S, Higuchi M, Seeburg PH, Takahashi R, Misawa H, Kwak S (2010) Induced loss of ADAR2 engenders slow death of motor neurons from $Q / R$ site-unedited GluR2. J Neurosci 30:11917-11925. doi:10.1523/ jneurosci.2021-10.2010

79. Highstein SM, Karabelas A, Baker R, McCrea RA (1982) Comparison of the morphology of physiologically identified abducens motor and internuclear neurons in the cat: a light microscopic study employing the intracellular injection of horseradish peroxidase. J Comp Neurol 208:369-381. doi:10.1002/cne.902080407

80. Hochstim C, Deneen B, Lukaszewicz A, Zhou Q, Anderson DJ (2008) Identification of positionally distinct astrocyte subtypes whose identities are specified by a homeodomain code. Cell 133:510-522

81. Hollyday M, Hamburger V (1976) Reduction of the naturally occurring motor neuron loss by enlargement of the periphery. $\mathrm{J}$ Comp Neurol 170:311-320. doi:10.1002/cne.901700304

82. Huang C, Tong J, Bi F, Zhou H, Xia XG (2012) Mutant TDP43 in motor neurons promotes the onset and progression of ALS in rats. J Clin Invest 122:107-118. doi:10.1172/jci59130

83. Ilieva HS, Yamanaka K, Malkmus S, Kakinohana O, Yaksh T, Marsala M, Cleveland DW (2008) Mutant dynein (Loa) triggers proprioceptive axon loss that extends survival only in the SOD1 ALS model with highest motor neuron death. Proc Natl Acad Sci USA 105:12599-12604. doi:10.1073/ pnas.0805422105

84. Jaarsma D, Teuling E, Haasdijk ED, De Zeeuw CI, Hoogenraad CC (2008) Neuron-specific expression of mutant superoxide dismutase is sufficient to induce amyotrophic lateral sclerosis in transgenic mice. J Neurosci 28:2075-2088. doi:10.1523/ jneurosci.5258-07.2008

85. Jacoby J, Ko K, Weiss C, Rushbrook JI (1990) Systematic variation in myosin expression along extraocular muscle fibres of the adult rat. J Muscle Res Cell Motil 11:25-40

86. Joksimovic M, Yun BA, Kittappa R, Anderegg AM, Chang WW, Taketo MM, McKay RD, Awatramani RB (2009) Wnt antagonism of Shh facilitates midbrain floor plate neurogenesis. Nat Neurosci 12:125-131. doi:10.1038/nn.2243

87. Kanai K, Shibuya K, Sato Y, Misawa S, Nasu S, Sekiguchi Y, Mitsuma S, Isose S, Fujimaki Y, Ohmori S (2012) Motor axonal excitability properties are strong predictors for survival in amyotrophic lateral sclerosis. J Neurol Neurosurg Psychiatry 83:734-738

88. Kang SH, Fukaya M, Yang JK, Rothstein JD, Bergles DE (2010) $\mathrm{NG}^{+}{ }^{+} \mathrm{CNS}$ glial progenitors remain committed to the 
oligodendrocyte lineage in postnatal life and following neurodegeneration. Neuron 68:668-681

89. Kang SH, Li Y, Fukaya M, Lorenzini I, Cleveland DW, Ostrow LW, Rothstein JD, Bergles DE (2013) Degeneration and impaired regeneration of gray matter oligodendrocytes in amyotrophic lateral sclerosis. Nat Neurosci 16:571-579

90. Kaplan A, Spiller KJ, Towne C, Kanning KC, Choe GT, Geber A, Akay T, Aebischer P, Henderson CE (2014) Neuronal matrix metalloproteinase-9 is a determinant of selective neurodegeneration. Neuron 81:333-348. doi:10.1016/j. neuron.2013.12.009

91. Kaspar BK, Llado J, Sherkat N, Rothstein JD, Gage FH (2003) Retrograde viral delivery of IGF-1 prolongs survival in a mouse ALS model. Science 301:839-842. doi:10.1126/ science. 1086137

92. Kawamura Y, Dyck PJ, Shimono M, Okazaki H, Doi J, Tateishi H (1981) Morphometric comparison of the vulnerability of peripheral motor and sensory neurons in amyotrophic lateral sclerosis. J Neuropathol Exp Neurol 40:667-675

93. Kernell D, Zwaagstra B (1981) Input conductance axonal conduction velocity and cell size among hindlimb motoneurones of the cat. Brain Res 204:311-326

94. Kiaei M, Kipiani K, Calingasan NY, Wille E, Chen J, Heissig B, Rafii S, Lorenzl S, Beal MF (2007) Matrix metalloproteinase-9 regulates TNF-alpha and FasL expression in neuronal, glial cells and its absence extends life in a transgenic mouse model of amyotrophic lateral sclerosis. Exp Neurol 205:74-81. doi:10.1016/j.expneurol.2007.01.036

95. Kiernan JA, Hudson AJ (1993) Changes in shapes of surviving motor neurons in amyotrophic lateral sclerosis. Brain 116(Pt 1):203-215

96. Kiernan JA, Hudson AJ (1991) Changes in sizes of cortical and lower motor neurons in amyotrophic lateral sclerosis. Brain 114(Pt 2):843-853

97. Kim W, Kim J-S, Lee K-S, Gwoun Y-J, Kim J-M, Lee K-H (2007) Anticipation and phenotypic heterogeneity in Korean familial amyotrophic lateral sclerosis with superoxide dismutase 1 gene mutation. J Clin Neurol 3:38-44

98. Kubota M, Sakakihara Y, Uchiyama Y, Nara A, Nagata T, Nitta H, Ishimoto K, Oka A, Horio K, Yanagisawa M (2000) New ocular movement detector system as a communication tool in ventilator-assisted Werdnig-Hoffmann disease. Dev Med Child Neurol 42:61-64

99. Kuo JJ, Schonewille M, Siddique T, Schults AN, Fu R, Bär PR, Anelli R, Heckman CJ, Kroese AB (2004) Hyperexcitability of cultured spinal motoneurons from presymptomatic ALS mice. J Neurophysiol 91:571-575

100. Kwak S, Kawahara Y (2005) Deficient RNA editing of GluR2 and neuronal death in amyotropic lateral sclerosis. J Mol Med 83:110-120

101. Kwiatkowski TJ, Bosco D, Leclerc A, Tamrazian E, Vanderburg C, Russ C, Davis A, Gilchrist J, Kasarskis E, Munsat $\mathrm{T}$ (2009) Mutations in the FUS/TLS gene on chromosome 16 cause familial amyotrophic lateral sclerosis. Science 323:1205-1208

102. Lagier-Tourenne C, Polymenidou M, Cleveland DW (2010) TDP-43 and FUS/TLS: emerging roles in RNA processing and neurodegeneration. Hum Mol Genet 19:R46-R64. doi:10.1093/hmg/ddq137

103. Laslo P, Lipski J, Nicholson LF, Miles GB, Funk GD (2001) GluR2 AMPA receptor subunit expression in motoneurons at low and high risk for degeneration in amyotrophic lateral sclerosis. Exp Neurol 169:461-471

104. Lautenschlaeger J, Prell T, Grosskreutz J (2012) Endoplasmic reticulum stress and the ER mitochondria calcium cycle in amyotrophic lateral sclerosis. Amyotroph Lateral Scler 13:166-177

105. Lawyer T Jr, Netsky MG (1953) Amyotrophic lateral sclerosis. AMA Arch Neurol Psychiatry 69:171-192

106. Lee Y, Morrison BM, Li Y, Lengacher S, Farah MH, Hoffman PN, Liu Y, Tsingalia A, Jin L, Zhang PW et al (2012) Oligodendroglia metabolically support axons and contribute to neurodegeneration. Nature 487:443-448. doi:10.1038/ nature 11314

107. Leroy F, d'Incamps BL, Imhoff-Manuel RD, Zytnicki D (2014) Early intrinsic hyperexcitability does not contribute to motoneuron degeneration in amyotrophic lateral sclerosis. eLife 3:e04046

108. Liddelow SA, Guttenplan KA, Clarke LE, Bennett FC, Bohlen CJ, Schirmer L, Bennett ML, Munch AE, Chung WS, Peterson TC et al (2017) Neurotoxic reactive astrocytes are induced by activated microglia. Nature. doi:10.1038/ nature21029 (Epub ahead of print)

109. Lim GP, Backstrom JR, Cullen MJ, Miller CA, Atkinson RD, Tokes ZA (1996) Matrix metalloproteinases in the neocortex and spinal cord of amyotrophic lateral sclerosis patients. J Neurochem 67:251-259

110. Lin J, Wu H, Tarr PT, Zhang C-Y, Wu Z, Boss O, Michael LF, Puigserver P, Isotani E, Olson EN (2002) Transcriptional coactivator PGC- $1 \alpha$ drives the formation of slow-twitch muscle fibres. Nature 418:797-801

111. Liu KX, Edwards B, Lee S, Finelli MJ, Davies B, Davies KE, Oliver PL (2015) Neuron-specific antioxidant OXR1 extends survival of a mouse model of amyotrophic lateral sclerosis. Brain 138:1167-1181. doi:10.1093/brain/awv039

112. Lobsiger CS, Boillee S, McAlonis-Downes M, Khan AM, Feltri ML, Yamanaka K, Cleveland DW (2009) Schwann cells expressing dismutase active mutant SOD1 unexpectedly slow disease progression in ALS mice. Proc Natl Acad Sci USA 106:4465-4470. doi:10.1073/pnas.0813339106

113. Lorenzl S, Narr S, Angele B, Krell HW, Gregorio J, Kiaei M, Pfister HW, Beal MF (2006) The matrix metalloproteinases inhibitor Ro 28-2653 [correction of Ro 26-2853] extends survival in transgenic ALS mice. Exp Neurol 200:166-171. doi:10.1016/j.expneurol.2006.01.026

114. Lorenzo LE, Barbe A, Portalier P, Fritschy JM, Bras H (2006) Differential expression of GABAA and glycine receptors in ALS-resistant vs. ALS-vulnerable motoneurons: possible implications for selective vulnerability of motoneurons. Eur J Neurosci 23:3161-3170. doi:10.1111/j.1460-9568.2006.04863.x

115. Mancuso R, Martinez-Muriana A, Leiva T, Gregorio D, Ariza L, Morell M, Esteban-Perez J, Garcia-Redondo A, Calvo AC, Atencia-Cibreiro G et al (2016) Neuregulin-1 promotes functional improvement by enhancing collateral sprouting in SOD1(G93A) ALS mice and after partial muscle denervation. Neurobiol Dis 95:168-178. doi:10.1016/j.nbd.2016.07.023

116. Maragakis NJ, Rothstein JD (2006) Mechanisms of disease: astrocytes in neurodegenerative disease. Nat Clin Pract Neuro 2:679-689

117. Marchetto MC, Muotri AR, Mu Y, Smith AM, Cezar GG, Gage FH (2008) Non-cell-autonomous effect of human SOD1 G37R astrocytes on motor neurons derived from human embryonic stem cells. Cell Stem Cell 3:649-657

118. Martin E, Cazenave W, Cattaert D, Branchereau P (2013) Embryonic alteration of motoneuronal morphology induces hyperexcitability in the mouse model of amyotrophic lateral sclerosis. Neurobiol Dis 54:116-126. doi:10.1016/j. nbd.2013.02.011

119. Maselli RA, Wollman RL, Leung C, Distad B, Palombi S, Richman DP, Salazar-Grueso EF, Roos RP (1993) 
Neuromuscular transmission in amyotrophic lateral sclerosis. Muscle Nerve 16:1193-1203

120. Mavlyutov TA, Guo L-W, Epstein ML, Ruoho AE (2015) Role of the sigma-1 receptor in amyotrophic lateral sclerosis (ALS). J Pharmacol Sci 127:10-16

121. McMahon AP, Bradley A (1990) The Wnt-1 (int-1) protooncogene is required for development of a large region of the mouse brain. Cell 62:1073-1085

122. Mendell LM (2005) The size principle: a rule describing the recruitment of motoneurons. J Neurophysiol 93:3024-3026

123. Mertens J, Paquola AC, Ku M, Hatch E, Bohnke L, Ladjevardi $\mathrm{S}$, McGrath S, Campbell $\mathrm{B}$, Lee $\mathrm{H}$, Herdy JR et al (2015) Directly reprogrammed human neurons retain agingassociated transcriptomic signatures and reveal age-related nucleocytoplasmic defects. Cell Stem Cell 17:705-718. doi:10.1016/j.stem.2015.09.001

124. Mesci P, Zaidi S, Lobsiger CS, Millecamps S, Escartin C, Seilhean D, Sato H, Mallat M, Boillee S (2015) System xC- is a mediator of microglial function and its deletion slows symptoms in amyotrophic lateral sclerosis mice. Brain 138:53-68. doi:10.1093/brain/awu312

125. Meyer K, Ferraiuolo L, Miranda CJ, Likhite S, McElroy S, Renusch S, Ditsworth D, Lagier-Tourenne C, Smith RA, Ravits J (2014) Direct conversion of patient fibroblasts demonstrates non-cell autonomous toxicity of astrocytes to motor neurons in familial and sporadic ALS. Proc Natl Acad Sci USA 111:829-832

126. Millecamps S, Nicolle D, Ceballos-Picot I, Mallet J, Barkats M (2001) Synaptic sprouting increases the uptake capacities of motoneurons in amyotrophic lateral sclerosis mice. Proc Natl Acad Sci USA 98:7582-7587. doi:10.1073/ pnas. 131031098

127. Miller TM, Kim SH, Yamanaka K, Hester M, Umapathi $P$, Arnson H, Rizo L, Mendell JR, Gage FH, Cleveland DW et al (2006) Gene transfer demonstrates that muscle is not a primary target for non-cell-autonomous toxicity in familial amyotrophic lateral sclerosis. Proc Natl Acad Sci USA 103:19546-19551. doi:10.1073/pnas.0609411103

128. Mitchell JC, McGoldrick P, Vance C, Hortobagyi T, Sreedharan J, Rogelj B, Tudor EL, Smith BN, Klasen C, Miller CC et al (2013) Overexpression of human wild-type FUS causes progressive motor neuron degeneration in an age- and dose-dependent fashion. Acta Neuropathol 125:273-288. doi:10.1007/s00401-012-1043-Z

129. Mizuno Y, Fujita Y, Takatama M, Okamoto K (2012) Comparison of phosphorylated TDP-43-positive inclusions in oculomotor neurons in patients with non-ALS and ALS disorders. $\mathbf{J}$ Neurol Sci 315:20-25. doi:10.1016/j.jns.2011.12.012

130. Molofsky AV, Kelley KW, Tsai HH, Redmond SA, Chang SM, Madireddy L, Chan JR, Baranzini SE, Ullian EM, Rowitch DH (2014) Astrocyte-encoded positional cues maintain sensorimotor circuit integrity. Nature 509:189-194. doi:10.1038/nature13161

131. Mong J, Panman L, Alekseenko Z, Kee N, Stanton LW, Ericson J, Perlmann T (2014) Transcription factor-induced lineage programming of noradrenaline and motor neurons from embryonic stem cells. Stem Cells 32:609-622. doi:10.1002/ stem. 1585

132. Morisaki Y, Niikura M, Watanabe M, Onishi K, Tanabe S, Moriwaki Y, Okuda T, Ohara S, Murayama S, Takao M et al (2016) Selective expression of osteopontin in ALS-resistant motor neurons is a critical determinant of late phase neurodegeneration mediated by matrix metalloproteinase-9. Sci Rep 6:27354. doi:10.1038/srep27354

133. Muller D, Cherukuri P, Henningfeld K, Poh CH, Wittler L, Grote P, Schluter O, Schmidt J, Laborda J, Bauer SR et al (2014) Dlk1 promotes a fast motor neuron biophysical signature required for peak force execution. Science 343:1264-1266. doi:10.1126/science. 1246448

134. Nagai M, Re DB, Nagata T, Chalazonitis A, Jessell TM, Wichterle H, Przedborski S (2007) Astrocytes expressing ALSlinked mutated SOD1 release factors selectively toxic to motor neurons. Nat Neurosci 10:615-622

135. Nardo G, Iennaco R, Fusi N, Heath PR, Marino M, Trolese MC, Ferraiuolo L, Lawrence N, Shaw PJ, Bendotti C (2013) Transcriptomic indices of fast and slow disease progression in two mouse models of amyotrophic lateral sclerosis. Brain 136:3305-3332. doi:10.1093/brain/awt250

136. Neumann M, Sampathu DM, Kwong LK, Truax AC, Micsenyi MC, Chou TT, Bruce J, Schuck T, Grossman M, Clark CM (2006) Ubiquitinated TDP-43 in frontotemporal lobar degeneration and amyotrophic lateral sclerosis. Science 314:130-133

137. Nimchinsky EA, Young WG, Yeung G, Shah RA, Gordon JW, Bloom FE, Morrison JH, Hof PR (2000) Differential vulnerability of oculomotor, facial, and hypoglossal nuclei in G86R superoxide dismutase transgenic mice. J Comp Neurol 416:112-125

138. Ozdinler PH, Benn S, Yamamoto TH, Guzel M, Brown RH Jr, Macklis JD (2011) Corticospinal motor neurons and related subcerebral projection neurons undergo early and specific neurodegeneration in hSOD1G(9)(3)A transgenic ALS mice. J Neurosci 31:4166-4177. doi:10.1523/ jneurosci.4184-10.2011

139. Pattyn A, Morin X, Cremer H, Goridis C, Brunet JF (1997) Expression and interactions of the two closely related homeobox genes Phox2a and Phox2b during neurogenesis. Development 124:4065-4075

140. Perez-Balaguer A, Puelles E, Wurst W, Martinez S (2009) Shh dependent and independent maintenance of basal midbrain. Mech Dev 126:301-313. doi:10.1016/j.mod.2009.03.001

141. Piccione EA, Sletten DM, Staff NP, Low PA (2015) Autonomic system and amyotrophic lateral sclerosis. Muscle Nerve 51:676-679. doi:10.1002/mus.24457

142. Porter JD (2002) Extraocular muscle: cellular adaptations for a diverse functional repertoire. Ann N Y Acad Sci 956:7-16

143. Porter JD, Khanna S, Kaminski HJ, Rao JS, Merriam AP, Richmonds CR, Leahy P, Li J, Andrade FH (2001) Extraocular muscle is defined by a fundamentally distinct gene expression profile. Proc Natl Acad Sci USA 98:12062-12067. doi:10.1073/ pnas. 211257298

144. Prakash N, Brodski C, Naserke T, Puelles E, Gogoi R, Hall A, Panhuysen M, Echevarria D, Sussel L, Weisenhorn DM et al (2006) A Wnt1-regulated genetic network controls the identity and fate of midbrain-dopaminergic progenitors in vivo. Development 133:89-98. doi:10.1242/dev.02181

145. Prakash N, Puelles E, Freude K, Trumbach D, Omodei D, Di Salvio M, Sussel L, Ericson J, Sander M, Simeone A et al (2009) Nk6-1 controls the identity and fate of red nucleus and oculomotor neurons in the mouse midbrain. Development 136:2545-2555. doi:10.1242/dev.031781

146. Puelles E, Acampora D, Lacroix E, Signore M, Annino A, Tuorto F, Filosa S, Corte G, Wurst W, Ang SL et al (2003) Otx dose-dependent integrated control of antero-posterior and dorso-ventral patterning of midbrain. Nat Neurosci 6:453460. doi:10.1038/nn1037

147. Pun S, Santos AF, Saxena S, Xu L, Caroni P (2006) Selective vulnerability and pruning of phasic motoneuron axons in motoneuron disease alleviated by CNTF. Nat Neurosci 9:408-419

148. Renton AE, Majounie E, Waite A, Simón-Sánchez J, Rollinson S, Gibbs JR, Schymick JC, Laaksovirta H, Van Swieten JC, Myllykangas L (2011) A hexanucleotide repeat expansion in C9ORF72 is the cause of chromosome 9p21-linked ALSFTD. Neuron 72:257-268 
149. Riascos D, de Leon D, Baker-Nigh A, Nicholas A, Yukhananov R, Bu J, Wu CK, Geula C (2011) Age-related loss of calcium buffering and selective neuronal vulnerability in Alzheimer's disease. Acta Neuropathol 122:565-576. doi:10.1007/s00401-011-0865-4

150. Rinholm JE, Hamilton NB, Kessaris N, Richardson WD, Bergersen LH, Attwell D (2011) Regulation of oligodendrocyte development and myelination by glucose and lactate. $\mathrm{J}$ Neurosci 31:538-548. doi:10.1523/jneurosci.3516-10.2011

151. Rizzo F, Riboldi G, Salani S, Nizzardo M, Simone C, Corti S, Hedlund E (2014) Cellular therapy to target neuroinflammation in amyotrophic lateral sclerosis. Cell Mol Life Sci 71:999-1015

152. Robinson DA (1970) Oculomotor unit behavior in the monkey. J Neurophysiol 33:393-403

153. Rosen DR, Siddique T, Patterson D, Figlewicz DA, Sapp P, Hentati A, Donaldson D, Goto J, O'Regan JP, Deng HX et al (1993) Mutations in $\mathrm{Cu} / \mathrm{Zn}$ superoxide dismutase gene are associated with familial amyotrophic lateral sclerosis. Nature 362:59-62. doi:10.1038/362059a0

154. Rossi AC, Mammucari C, Argentini C, Reggiani C, Schiaffino S (2010) Two novel/ancient myosins in mammalian skeletal muscles: MYH14/7b and MYH15 are expressed in extraocular muscles and muscle spindles. J Physiol 588:353-364. doi:10.1113/ jphysiol.2009.181008

155. Rouaux C, Panteleeva I, Rene F, Gonzalez de Aguilar JL, Echaniz-Laguna A, Dupuis L, Menger Y, Boutillier AL, Loeffler JP (2007) Sodium valproate exerts neuroprotective effects in vivo through CREB-binding protein-dependent mechanisms but does not improve survival in an amyotrophic lateral sclerosis mouse model. J Neurosci 27:5535-5545. doi:10.1523/ jneurosci.1139-07.2007

156. Ruegsegger C, Maharjan N, Goswami A, de L'Etang AF, Weis J, Troost D, Heller M, Gut H, Saxena S (2015) Aberrant association of misfolded SOD1 with Na/KATPase-alpha3 impairs its activity and contributes to motor neuron vulnerability in ALS. Acta Neuropathol. doi:10.1007/s00401-015-1510-4

157. Rushbrook J, Weiss C, Ko K, Feuerman M, Carleton S, Ing A, Jacoby J (1994) Identification of alpha-cardiac myosin heavy chain mRNA and protein in extraocular muscle of the adult rabbit. J Muscle Res Cell Motil 15:505-515

158. Saxena S, Cabuy E, Caroni P (2009) A role for motoneuron subtype-selective ER stress in disease manifestations of FALS mice. Nat Neurosci 12:627-636. doi:10.1038/nn.2297

159. Saxena S, Roselli F, Singh K, Leptien K, Julien J-P, GrosLouis F, Caroni P (2013) Neuroprotection through excitability and mTOR required in ALS motoneurons to delay disease and extend survival. Neuron 80:80-96

160. Schaefer AM, Sanes JR, Lichtman JW (2005) A compensatory subpopulation of motor neurons in a mouse model of amyotrophic lateral sclerosis. J Comp Neurol 490:209-219. doi:10.1002/cne.20620

161. Schafer DP, Lehrman EK, Kautzman AG, Koyama R, Mardinly AR, Yamasaki R, Ransohoff RM, Greenberg ME, Barres BA, Stevens B (2012) Microglia sculpt postnatal neural circuits in an activity and complement-dependent manner. Neuron 74:691-705

162. Schoser BG, Blottner D (1999) Matrix metalloproteinases MMP-2, MMP-7 and MMP-9 in denervated human muscle. NeuroReport 10:2795-2797

163. Seijffers R, Zhang J, Matthews JC, Chen A, Tamrazian E, Babaniyi O, Selig M, Hynynen M, Woolf CJ, Brown RH Jr (2014) ATF3 expression improves motor function in the ALS mouse model by promoting motor neuron survival and retaining muscle innervation. Proc Natl Acad Sci USA 111:1622-1627. doi:10.1073/pnas.1314826111
164. Sharma A, Lyashchenko AK, Lu L, Nasrabady SE, Elmaleh M, Mendelsohn M, Nemes A, Tapia JC, Mentis GZ, Shneider NA (2016) ALS-associated mutant FUS induces selective motor neuron degeneration through toxic gain of function. Nat Commun 7:10465. doi:10.1038/ncomms 10465

165. Silva D, Dikkes P, Barnes M, Lopez MF (2009) Decreased motoneuron survival in Igf2 null mice after sciatic nerve transection. NeuroReport 20:1414-1418. doi:10.1097/ WNR.0b013e328330b735

166. Sloan SA, Barres BA (2014) Mechanisms of astrocyte development and their contributions to neurodevelopmental disorders. Curr Opin Neurobiol 27:75-81

167. Spencer R, Porter J (1988) Structural organization of the extraocular muscles. Rev Oculomot Res 2:33-79

168. Spiller KJ, Cheung CJ, Restrepo CR, Kwong LK, Stieber AM, Trojanowski JQ, Lee VM (2016) Selective motor neuron resistance and recovery in a new inducible mouse model of TDP43 proteinopathy. J Neurosci 36:7707-7717. doi:10.1523/ jneurosci.1457-16.2016

169. Sudria-Lopez E, Koppers M, de Wit M, van der Meer C, Westeneng HJ, Zundel CA, Youssef SA, Harkema L, de Bruin A, Veldink JH et al (2016) Full ablation of C9orf72 in mice causes immune system-related pathology and neoplastic events but no motor neuron defects. Acta Neuropathol. doi:10.1007/ s00401-016-1581-x

170. Sun S, Ling SC, Qiu J, Albuquerque CP, Zhou Y, Tokunaga S, Li H, Qiu H, Bui A, Yeo GW et al (2015) ALS-causative mutations in FUS/TLS confer gain and loss of function by altered association with SMN and U1-snRNP. Nat Commun 6:6171. doi: $10.1038 /$ ncomms 7171

171. Swinnen B, Robberecht W (2014) The phenotypic variability of amyotrophic lateral sclerosis. Nat Rev Neurol 10:661-670. doi:10.1038/nrneurol.2014.184

172. Syed N, Kim HA (2010) Soluble neuregulin and Schwann cell myelination: a therapeutic potential for improving remyelination of adult axons. Mol Cell Pharmacol 2:161-167. doi:10.4255/mcpharmacol.10.22

173. Tateno M, Sadakata H, Tanaka M, Itohara S, Shin RM, Miura M, Masuda M, Aosaki T, Urushitani M, Misawa H et al (2004) Calcium-permeable AMPA receptors promote misfolding of mutant SOD1 protein and development of amyotrophic lateral sclerosis in a transgenic mouse model. Hum Mol Genet 13:2183-2196. doi:10.1093/hmg/ddh246

174. Tjust AE, Brannstrom T, Pedrosa-Domellof F (2012) Unaffected motor endplate occupancy in eye muscles of ALS G93A mouse model. Front Biosci (Schol Ed) 4:1547-1555

175. Torres-Torrelo J, Torres B, Carrascal L (2014) Modulation of the input-output function by GABAA receptor-mediated currents in rat oculomotor nucleus motoneurons. J Physiol 592:5047-5064. doi:10.1113/jphysiol.2014.276576

176. Torres-Torrelo J, Rodríguez-Rosell D, Nunez-Abades P, Carrascal L, Torres B (2012) Glutamate modulates the firing rate in oculomotor nucleus motoneurons as a function of the recruitment threshold current. J Physiol 590:3113-3127

177. Ulfhake B, Kellerth JO (1981) A quantitative light microscopic study of the dendrites of cat spinal $\alpha$-motoneurons after intracellular staining with horseradish peroxidase. J Comp Neurol 202:571-583. doi:10.1002/cne.902020409

178. Ullian EM, Christopherson KS, Barres BA (2004) Role for glia in synaptogenesis. Glia 47:209-216

179. Valdez G, Tapia JC, Lichtman JW, Fox MA, Sanes JR (2012) Shared resistance to aging and ALS in neuromuscular junctions of specific muscles. PLoS One 7:e34640

180. Van Den Bosch L, Schwaller B, Vleminckx V, Meijers B, Stork S, Ruehlicke T, Van Houtte E, Klaassen H, Celio MR, Missiaen $\mathrm{L}$ et al (2002) Protective effect of parvalbumin on excitotoxic 
motor neuron death. Exp Neurol 174:150-161. doi:10.1006/ exnr.2001.7858

181. Van Den Bosch L, Van Damme P, Bogaert E, Robberecht W (2006) The role of excitotoxicity in the pathogenesis of amyotrophic lateral sclerosis. BBA Mol Basis Dis 1762:1068-1082

182. Van Hoecke A, Schoonaert L, Lemmens R, Timmers M, Staats KA, Laird AS, Peeters E, Philips T, Goris A, Dubois B (2012) EPHA4 is a disease modifier of amyotrophic lateral sclerosis in animal models and in humans. Nat Med 18:1418-1422

183. Vance C, Rogelj B, Hortobágyi T, De Vos KJ, Nishimura AL, Sreedharan J, Hu X, Smith B, Ruddy D, Wright P (2009) Mutations in FUS, an RNA processing protein, cause familial amyotrophic lateral sclerosis type 6. Science 323:1208-1211

184. Venugopal S, Hsiao C-F, Sonoda T, Wiedau-Pazos M, Chandler SH (2015) Homeostatic dysregulation in membrane properties of masticatory motoneurons compared with oculomotor neurons in a mouse model for amyotrophic lateral sclerosis. J Neurosci 35:707-720

185. Vinsant S, Mansfield C, Jimenez-Moreno R, Del Gaizo Moore V, Yoshikawa M, Hampton TG, Prevette D, Caress J, Oppenheim RW, Milligan C (2013) Characterization of early pathogenesis in the SOD1(G93A) mouse model of ALS: part II, results and discussion. Brain Behav 3:431-457. doi:10.1002/brb3.142

186. Wainger BJ, Kiskinis E, Mellin C, Wiskow O, Han SS, Sandoe J, Perez NP, Williams LA, Lee S, Boulting G (2014) Intrinsic membrane hyperexcitability of amyotrophic lateral sclerosis patient-derived motor neurons. Cell Rep 7:1-11

187. Walker AK, Spiller KJ, Ge G, Zheng A, Xu Y, Zhou M, Tripathy K, Kwong LK, Trojanowski JQ, Lee VM (2015) Functional recovery in new mouse models of ALS/FTLD after clearance of pathological cytoplasmic TDP-43. Acta Neuropathol 130:643660. doi:10.1007/s00401-015-1460-x

188. Wang L, Pytel P, Feltri ML, Wrabetz L, Roos RP (2012) Selective knockdown of mutant SOD1 in Schwann cells ameliorates disease in G85R mutant SOD1 transgenic mice. Neurobiol Dis 48:52-57. doi:10.1016/j.nbd.2012.05.014

189. Wasicky R, Horn AK, Buttner-Ennever JA (2004) Twitch and nontwitch motoneuron subgroups in the oculomotor nucleus of monkeys receive different afferent projections. J Comp Neurol 479:117-129. doi:10.1002/cne.20296

190. Wen X, Westergard T, Pasinelli P, Trotti D (2017) Pathogenic determinants and mechanisms of ALS/FTD linked to hexanucleotide repeat expansions in the C9orf72 gene. Neurosci Lett 636:16-26. doi:10.1016/j.neulet.2016.09.007

191. Wieczorek DF, Periasamy M, Butler-Browne GS, Whalen RG, Nadal-Ginard B (1985) Co-expression of multiple myosin heavy chain genes, in addition to a tissue-specific one, in extraocular musculature. J Cell Biol 101:618-629

192. Wong M, Martin LJ (2010) Skeletal muscle-restricted expression of human SOD1 causes motor neuron degeneration in transgenic mice. Hum Mol Genet 19:2284-2302. doi:10.1093/ hmg/ddq106

193. Woodhoo A, Sommer L (2008) Development of the Schwann cell lineage: from the neural crest to the myelinated nerve. Glia 56:1481-1490. doi:10.1002/glia.20723

194. Yamanaka K, Chun SJ, Boillee S, Fujimori-Tonou N, Yamashita H, Gutmann DH, Takahashi R, Misawa H, Cleveland DW (2008) Astrocytes as determinants of disease progression in inherited amyotrophic lateral sclerosis. Nat Neurosci 11:251-253

195. Ye W, Shimamura K, Rubenstein JL, Hynes MA, Rosenthal A (1998) FGF and Shh signals control dopaminergic and serotonergic cell fate in the anterior neural plate. Cell 93:755-766

196. Zhao W, Varghese M, Yemul S, Pan Y, Cheng A, Marano P, Hassan S, Vempati P, Chen F, Qian X (2011) Peroxisome proliferator activator receptor gamma coactivator-1alpha (PGC-1 $\alpha)$ improves motor performance and survival in a mouse model of amyotrophic lateral sclerosis. Mol Neurodegener 6:51

197. Zhou Y, Liu D, Kaminski HJ (2010) Myosin heavy chain expression in mouse extraocular muscle: more complex than expected. Invest Ophthalmol Vis Sci 51:6355-6363. doi:10.1167/iovs.10-5937

198. Zhou Y, Liu D, Kaminski HJ (2011) Pitx2 regulates myosin heavy chain isoform expression and multi-innervation in extraocular muscle. J Physiol 589:4601-4614. doi:10.1113/ jphysiol.2011.207076

199. Zimmermann L, Morado-Diaz CJ, Davis-Lopez de Carrizosa MA, de la Cruz RR, May PJ, Streicher J, Pastor AM, Blumer R (2013) Axons giving rise to the palisade endings of feline extraocular muscles display motor features. J Neurosci 33:2784-2793. doi:10.1523/jneurosci.4116-12.2013 